\title{
On the Conditional Effects of IMF Program Participation on Output Growth
}

\author{
Michael Binder \\ Marcel Bluhm
}

\author{
CESIFO WORKING PAPER NO. 3161 \\ CATEGory 7: MONETARy POLICY AND INTERNATIONAL FinANCE \\ August 2010
}

An electronic version of the paper may be downloaded

- from the SSRN website:

- from the RePEc website:

- from the CESifo website:

www.SSRN.com

www.RePEc.org

www.CESifo-group.org/wp 


\title{
On the Conditional Effects of IMF Program Participation on Output Growth
}

\begin{abstract}
The empirical evidence currently available in the literature regarding the effects of a country's IMF program participation on its output growth is rather mixed. To shed new evidence on this issue, in this paper we specify a state-dependent panel data model accounting in particular for program participation selection and the potential conditionality of the output growth effects of program participation on a country's degree of program implementation and institutional factors such as quality of governance, internal stability, health, and educational attainment. We find that the effects of IMF program participation on output growth vary systematically with the degree of program implementation as well as our index of institutional factors, and that these effects are positive only if the IMF program is implemented to a sufficient degree or if the program participation is coupled with sufficient progress in improving institutional quality.
\end{abstract}

JEL-Code: O11, O19, C33.

Keywords: IMF program participation, output growth, panel sample selection models, conditional pooling.

Michael Binder

Goethe University Frankfurt

House of Finance

Grueneburgplatz 1

Germany - 60323 Frankfurt am Main

mbinder@wiwi.uni-frankfurt.de
Marcel Bluhm

Goethe University Frankfurt

House of Finance

Grueneburgplatz 1

Germany-60323 Frankfurt am Main

bluhm@ifk-cfs.de

We are grateful for comments and suggestions from two conference discussants, Michel Beine and Jörg Breitung, as well as seminar and conference participants at Bonn University, CESifo Munich and Tuebingen University, as well as the Econometric Society World Congress 2010. 


\section{Introduction}

The International Monetary Fund (IMF) began its operations in 1945, and was conceived as an independent international organization helping to promote macroeconomic and financial stability as well as growth of the world economy. In the 1970s the IMF expanded its role towards providing on a conditional basis development assistance to countries that as a prerequisite for loan approval had to initiate economic and structural reforms as outlined by the IMF. ${ }^{1}$ While the IMF has often been criticized for failures in carrying out such development policy, in the wake of the recent financial crisis a number of calls have been made for an expanded role of the IMF. This paper re-considers the effects of a country's participation in IMF loan programs on its output growth, taking account of conditionality of these growth effects on the degree of program implementation as well as institutional factors such as quality of governance, internal stability, health, and educational attainment.

The IMF has been offering four types of loan arrangements involving policy conditions, the stand-by arrangement (SBA), the extended fund facility (EFF), the structural adjustment facility (SAF), and the enhanced structural adjustment facility (ESAF), subsequently replaced by the poverty reduction and growth facility (PRGF). Most of the IMF's assistance is provided through SBAs. Designed in 1952 to help countries with addressing short-term balance of payments problems, SBAs typically cover periods of one to two years. The EFF was set up in 1974 to help countries encountering long-term balance of payments problems requiring fundamental economic reforms. EFF loan arrangements usually cover three to five years. The SAF has been used since 1986, and is designed to provide assistance for low-income countries. The ESAF only differs slightly from the SAF, but involves stricter conditionality criteria and larger loan amounts. The ESAF was used since 1986; after the East-Asian crisis this facility was relabeled PRGF, as it was broadened to include poverty reduction and to grant governments larger scope in negotiating the policy conditions. Typically PRGF programs are pursued for up to four years. When conditionality is involved, the IMF assesses whether a country complies with the conditionality requirements; if so, the country can draw on the loan funds in pre-specified

\footnotetext{
${ }^{1}$ For a more detailed exposition, see Fritz-Krockow and Ramlogan (2007).
} 
intervals. $^{2}$

The previous empirical evidence regarding the effects of a country's participation in IMF loan programs on its output growth is rather mixed. Using political economy variables as instruments to address endogeneity issues, Barro and Lee (2005) find that the IMF loan program participation rate has a negative effect on output growth. ${ }^{3}$ Vreeland (2003), using counterfactual analysis, also finds evidence that program participation leads to a reduction of output growth. In contrast, Dicks-Mireaux, Mecagni and Schadler (2000), also using counterfactual analysis, find positive output growth effects of IMF program participation.

In this paper we provide new insights regarding the effects of a country's IMF program participation on its output growth by constructing and estimating a state-dependent panel data model accounting in particular for sample selection, for the endogeneity of program participation, and for the potential conditionality of the output growth effects of IMF program participation on a country's degree of program implementation and institutional factors such as quality of governance, internal stability, health, and educational attainment. We argue that capturing sample selection, program participation endogeneity, and state dependence of the effects is critical for properly measuring the effects of a country's IMF program participation on output growth. To cope with sample selection issues, we work with an equation system composed both of a program participation selection and an output growth (participation effects) equation; within this equation system, we account for the endogeneity of the program participation measure in the output growth equation using a two-step maximum likelihood estimator. We capture country-specific effects under the two alternatives of a random and a fixed effects model. To account for the state dependence of the output growth effects of IMF program participation, we use semi-parametric conditional pooling techniques to condition the effects of participation in IMF programs on a country's degree of program implementation and its institu-

\footnotetext{
${ }^{2}$ For the empirical work in this paper we will not discriminate between these different loan arrangement schemes. While SBAs in contrast to the other schemes cover elements of structural reforms only to a limited extent, for example in the form of exchange rate and pricing policies, SBAs often precede one of the other schemes simply because "there has not $[. .$.$] been enough time to assemble all the necessary elements of a comprehensive$ structural package" (Polak, 1991).

${ }^{3}$ Barro and Lee (2005) define the loan participation rate as the fraction of months during a five-years interval that a country operated under IMF loan programs.
} 
tional features as measured by our index comprising measures of quality of governance, internal stability, health, and educational attainment.

Using this novel econometric framework and a sample of annual data for 86 countries over the time period from 1975 to 2005, we provide evidence that the effects of IMF program participation on output growth vary systematically with the degree of program implementation as well as our index of institutional factors, and that these effects are positive only if IMF program participation is at a sufficiently advanced stage, or if the program participation is coupled with sufficient progress in improving institutional quality.

The remainder of this paper is structured as follows: Section 2 provides a review of the previous literature. Sections 3 and 4 describe our panel econometric framework, with Section 3 focussing on sample selection and endogeneity issues, and Section 4 describing our approach to modelling state dependence of the effects of IMF program participation. Section 5 describes the construction of our variables for modelling the state dependence of the effects of IMF program participation on a country's output growth. Section 6 presents our empirical results. Finally, Section 7 concludes. Further details regarding our econometric modelling framework and inference approach, further results checking on the robustness of our main findings and some details concerning the data set we collected for this paper are described in several appendices.

\section{Review of Previous Literature}

There are a number of notable contributions to the literature concerned with measuring the effects of a country's IMF loan program participation on output growth. Most of the contributions can be characterized as following one of three approaches: (i) the "before-after"-approach, (ii) the "withwithout"-approach, and (iii) regression-based approaches. ${ }^{4}$

The "before-after"-approach is based on the idea that, ceteris paribus, output growth that a country has experienced before/after entering an IMF loan program may be compared with output growth that the country experiences during participation in an IMF loan program. For example, Evrensel

\footnotetext{
${ }^{4}$ See also Vreeland (2003) and Dreher (2006) for a similar categorization of the literature.
} 
(2002) investigates the effects of IMF loan programs for a sample of 109 countries over the time period from 1971 to 1997 using lags of up to three years before and after program participation to conduct a "before-after" analysis. With respect to the output growth effects of program participation, she argues that the evidence is inconclusive. The main problem with the "before-after" approach, in any case, is that in practice it does not allow to fully account for country-specific factors that have bearing on the output growth effects of program participation.

The "with-without" approach rests on the assumption that the core features of countries that participate in IMF loan programs are the same as those of countries not participating in IMF loan programs. For example, using matching methods, Hutchison (2004) analyzes the differences in output growth between countries participating and those not participating in IMF loan programs, for a panel of 25 countries over the time period 1975 to 1997. Hutchison's (2004) results suggest that, once sample selection is controlled for using observed variables only, ${ }^{5}$ participation in IMF loan programs has no adverse effects on output growth. However, Hutchison's (2004) matching methods do not take into account any selection based on unobserved variables, and so his results may still be subject to sample selection bias. Bordo and Schwartz (2000) compare the performance of 24 Asian and LatinAmerican countries over the time period 1973 to 1999 and find that before the onset of currency or banking crises, output growth declines more strongly in countries not participating in IMF loan programs, though not to levels as low as of those countries participating in IMF loan programs. They find furthermore that countries not participating in IMF loan programs recover faster after currency and banking crises.

The majority of contributions to the empirical literature on the effects of IMF loan program participation on output growth employ regressionbased approaches. Dicks-Mireaux, Mecagni, and Schadler (2000) perform a counterfactual analysis using a panel data set for 74 countries over the time period from 1986 to 1991. Taking into account sample selection issues, they find significant, positive effects of IMF loan program participation on output growth. In contrast, Vreeland (2003) using a similar methodology for a panel

\footnotetext{
${ }^{5}$ See, for example, Heckman, Ichimura, and Todd (1998) for a distinction between selection based on observed variables versus selection based on unobserved variables.
} 
of 79 countries over the time period from 1970 to $1990,{ }^{6}$ finds a negative impact of IMF program participation on output growth. Bordo and Schwartz (2000), also using counterfactual analysis, find negative but insignificant effects on output growth during the onset of a currency or banking crisis, but positive and significant effects a year later. Their data set comprises 24 Asian and Latin-American countries and covers the time period from 1973 to 1998. Hutchison and Noy (2003), distinguishing between IMF program approval and successful completion of IMF programs, analyze the effects of IMF program participation on output growth in a sample of 65 developing countries over the time period from 1975 to 1997. Using counterfactual analysis, they find that participation in IMF loan programs results in shortrun output growth losses, though noting that these results appear entirely driven by the Latin-American countries in their sample. Finally, Barro and Lee (2005), using a set of political economy variables as instruments to correct for regressor endogeneity problems in a panel comprising 86 countries over the time period from 1975 to 2000 find that participation in IMF loan programs has a significantly negative effect on output growth.

\section{Panel Data Models with Sample Selection and Censored Endogenous Variables}

When using a regression framework to estimate the effects of IMF program participation on a country's output growth, two issues that need to be addressed are (i) endogeneity of the program participation measure in the output growth equation and (ii) sample selection. The first issue arises when explaining output growth with, inter alia, a country's participation in IMF loan programs, as one will need to distinguish whether a country's economic performance is causal for IMF program participation, or vice versa. The second issue arises when using non-randomly selected samples for model estimation, as then the fact that the output growth performance of countries that participate in IMF programs may systematically differ from that of those countries that do not participate needs to be addressed. ${ }^{7}$ Countries tend to participate in IMF loan programs when they encounter economic

\footnotetext{
${ }^{6}$ Vreeland (2003) also uses a larger data set, ranging from 1950 to 1990.

${ }^{7}$ As is well known, the investigation of such sample selection effects was pioneered in empirical microeconomics by Heckman (1979).
} 
problems, which implies that they are likely to experience an output growth process that is different from that of countries that do not turn to the IMF for assistance. It is thus sensible to analyze the output growth process of participating countries - that are likely to be in a situation of economic crisis - separately from the output growth process of non-participating countries, which in turn necessitates to correct for sample selection. As noted by Vella (1998), while sample selection has in the literature been commonly confronted in purely cross-sectional analyses, it is less frequently considered to be of concern in the estimation of panel models. This may in part be due to the perception that a panel model incorporating random or fixed effects will eliminate most forms of unobserved heterogeneity. However, consistency of the fixed effects estimator of a default fixed effects model not explicitly capturing the selection mechanism requires that the selection operates purely through the time-invariant country-specific terms, which appears to be rather unlikely. Consistency of the random effects estimator of the default random effects panel model requires the additional condition that the time-invariant country-specific effect and the model's disturbance term are uncorrelated.

\subsection{Random Effects Panel Model with Sample Selection and Endogeneity}

In the following we will first outline a random effects model to correct for sample selection as well as endogeneity of the IMF program participation measure in the output growth equation. Our exposition of this random effects model draws strongly upon Vella (1998) and Vella and Verbeek (1999). ${ }^{8}$ Consider the following random effects panel data model with sample selection and endogeneity:

\footnotetext{
${ }^{8}$ Vella and Verbeek (1999) discuss a model that inter alia allows for a broader range of functional forms than we wish to consider in this paper. Our model specification also differs from theirs in that unlike Vella and Verbeek (1999) we wish to allow for a larger number of regressors in the participation selection equation than in the participation effects equation.
} 


$$
y_{i t}^{*}=\mu_{i}+d_{i t} \theta+\boldsymbol{x}_{i t}^{\prime} \boldsymbol{\beta}+e_{i t}
$$

("participation effects equation"),

$$
d_{i t}^{*}=\alpha_{i}+\boldsymbol{z}_{i t}^{\prime} \boldsymbol{\gamma}+v_{i t}
$$

("participation selection equation"),

$$
\begin{aligned}
& d_{i t}^{*}=\left\{\begin{array}{l}
d_{i t}^{*} \text { if } d_{i t}^{*}>0, \\
0 \text { otherwise }
\end{array}\right. \\
& y_{i t}=\left\{\begin{array}{l}
y_{i t}^{*} \text { if } d_{i t}>0, \\
\text { "unspecified" otherwise }
\end{array}\right.
\end{aligned}
$$

$i=1,2, \ldots, N$, and $t=1,2, \ldots, T_{i}$, where $y_{i t}^{*}$ and $d_{i t}^{*}$ are latent endogenous variables for country $i$ and time period $t$ with observed counterparts $y_{i t}$ (output growth - participation effects measure) and $d_{i t}$ (IMF loan-quota ratio - measure of participation intensity). ${ }^{9}$ Also note that $\boldsymbol{x}_{i t}$ is a subset of $\boldsymbol{z}_{i t}$, and throughout our exposition in this section $\boldsymbol{z}_{i t}$ will be taken to be strictly exogenous.

Let us write the unobserved component of each equation as the sum of the country-specific random effect ( $\mu_{i}$ in Equation (1) and $\alpha_{i}$ in Equation $(2))$ and the time-specific idiosyncratic error term $\left(e_{i t}\right.$ in Equation (1) and $v_{i t}$ in Equation (2)):

$$
\epsilon_{i t}=\mu_{i}+e_{i t},
$$

and

$$
u_{i t}=\alpha_{i}+v_{i t}
$$

Defining $\boldsymbol{u}_{i}$ as the stacked $\left(T_{i} \times 1\right)$ vector of $u_{i t}$ 's for country $i, \boldsymbol{X}_{i}=$

\footnotetext{
${ }^{9}$ While the availability of data on output growth is per se not tied to a country participating in an IMF loan program (that is, $d_{i t} \geq 0$ ), $y_{i t}$ under non-participation is unobserved from the perspective of the sample selection model equations in (1) and (2), in that it is then driven by a different model of output growth.
} 
$\left(\boldsymbol{x}_{i 1}, \boldsymbol{x}_{i 2}, \ldots, \boldsymbol{x}_{i T_{i}}\right)^{\prime}$, and $\boldsymbol{Z}_{i}=\left(\boldsymbol{z}_{i 1}, \boldsymbol{z}_{i 2}, \ldots, \boldsymbol{z}_{i T_{i}}\right)^{\prime}$, we assume that

$$
\boldsymbol{u}_{i} \mid \boldsymbol{Z}_{i} \stackrel{i i d}{\sim} N\left(0, \sigma_{\alpha}^{2} \iota \iota^{\prime}+\sigma_{v}^{2} \boldsymbol{I}\right)
$$

with $\iota$ being a $T_{i} \times 1$ vector of ones. Equation (7) restricts $\alpha_{i}$ and $v_{i t}$ to be independent across $i$, and $v_{i t}$ is restricted to be intertemporally uncorrelated and homoskedastic. We also assume that

$$
E\left(\epsilon_{i t} \mid \boldsymbol{Z}_{i}, \boldsymbol{u}_{i}\right)=\tau_{1} u_{i t}+\tau_{2} \bar{u}_{i}
$$

where $\bar{u}_{i}=T_{i}^{-1} \sum_{t=1}^{T_{i}} u_{i t}$, and $\tau_{1}$ and $\tau_{2}$ are parameters. Note that Equation (8) allows for $d_{i t}$ and $\epsilon_{i t}$ to be correlated, capturing endogeneity of the IMF loan-quota ratio in the output growth equation as arising through the program participation selection mechanism specified in Equation (2). Also, through $\tau_{2} \neq 0$ Equation (8) allows $e_{i t}$ to be intertemporally correlated and heteroskedastic.

Conditioning Equation (1) on the selection outcomes, $\boldsymbol{d}_{i}$, as well as the regressors in $\boldsymbol{X}_{i}$, and observing Equation (8) yields

$$
\begin{aligned}
E\left(y_{i t}^{*} \mid \boldsymbol{Z}_{i}, \boldsymbol{d}_{i}\right) & =d_{i t} \theta+\boldsymbol{x}_{i t}^{\prime} \boldsymbol{\beta}+E\left(\epsilon_{i t} \mid \boldsymbol{Z}_{i}, \boldsymbol{d}_{i}\right) \\
& =d_{i t} \theta+\boldsymbol{x}_{i t}^{\prime} \boldsymbol{\beta}+\tau_{1} u_{i t}+\tau_{2} \bar{u}_{i} .
\end{aligned}
$$

To obtain the sample selection correction terms in $u_{i t}$ and $\bar{u}_{i}$ on the righthand side of Equation (9), Vella and Verbeek propose to compute

$$
E\left[u_{i t} \mid \boldsymbol{Z}_{i}, \boldsymbol{d}_{i}\right]=\int\left[\alpha_{i}+E\left(v_{i t} \mid \boldsymbol{Z}_{i}, \boldsymbol{d}_{i}, \alpha_{i}\right)\right] f\left(\alpha_{i} \mid \boldsymbol{Z}_{i}, \boldsymbol{d}_{i}\right) d \alpha_{i},
$$

where $f\left(\alpha_{i} \mid \boldsymbol{Z}_{i}, \boldsymbol{d}_{i}\right)$ denotes the conditional density of $\alpha_{i}$, and $v_{i t}$ in terms of its expectation conditional on $\boldsymbol{Z}_{i}, \boldsymbol{d}_{i}$, and $\alpha_{i}$ is the generalized residual from estimation of the panel Tobit model in Equation (2). ${ }^{10}$ The conditional density of $\alpha_{i}$ can be obtained from

$$
f\left(\alpha_{i} \mid \boldsymbol{Z}_{i}, \boldsymbol{d}_{i}\right)=\frac{f\left(\boldsymbol{d}_{i} \mid \boldsymbol{Z}_{i}, \alpha_{i}\right) f\left(\alpha_{i}\right)}{f\left(\boldsymbol{d}_{i} \mid \boldsymbol{Z}_{i}\right)},
$$

\footnotetext{
${ }^{10}$ See Gourieroux, Monfort, Renault, and Trognon (1987) for a definition of the generalized residuals we work with here.
} 
with $f$ generically denoting density functions, and where

$$
f\left(\boldsymbol{d}_{i} \mid \boldsymbol{Z}_{i}\right)=\int \prod_{t=1}^{T_{i}} f\left(d_{i t} \mid \boldsymbol{Z}_{i}, \alpha_{i}\right) f\left(\alpha_{i}\right) d \alpha_{i}
$$

After obtaining the conditional expectation of $u_{i t}$ in Equation (10), the output growth equation in (1) can be estimated, including $u_{i t}$ and $\bar{u}_{i}$ as additional variables to correct for sample selection while also allowing for endogeneity of $d_{i t}$. The functional form of Equation (10) as well as details concerning the computation of the standard errors for the estimates of $\theta, \beta, \tau_{1}$, and $\tau_{2}$ can be found in Appendix A.

If $e_{i t}$ is to be restricted to be intertemporally uncorrelated, then Equation (8) reduces to

$$
E\left(\epsilon_{i t} \mid \boldsymbol{Z}_{i}, \boldsymbol{u}_{i}\right)=\tau_{1} u_{i t}
$$

implying that Equation (10) simplifies to

$$
E\left[u_{i t} \mid \boldsymbol{Z}_{i}, d_{i t}\right]=\int\left[\alpha_{i}+E\left(v_{i t} \mid \boldsymbol{Z}_{i}, d_{i t}, \alpha_{i}\right)\right] f\left(\alpha_{i} \mid \boldsymbol{Z}_{i}, d_{i t}\right) d \alpha_{i} .
$$

\subsection{Fixed Effects Panel Model with Sample Selection and Endogeneity}

Semykina and Wooldridge (2005) propose a fixed effects specification of a panel data model closely related to Equations (1) to (4). In what follows we will invoke Semykina and Wooldridge's (2005) modelling of the fixed effects, decomposing the fixed effects into a systematic component driven by observables (the variables in $\boldsymbol{g}_{i}$ ) as well as a random unobserved component, and then embed the resultant model within the estimation and inference procedure discussed in Sub-Section 3.1. ${ }^{11}$

Following Semykina and Wooldridge (2005), let us thus invoke a Mundlak (1978) type decomposition of the country-specific fixed effect in Equation

\footnotetext{
${ }^{11}$ Semykina and Wooldridge (2005) provide a different two-step estimation and inference procedure for a panel model with a Probit specification of the selection mechanism than we propose in this sub-section for a panel model with a Tobit specification of the selection mechanism. For our data set, the procedure we outline here appears to be more robust to the selection of variables in $\boldsymbol{g}_{i}$ than the Semykina and Wooldridge (2005) procedure. A systematic comparison of our procedure with that of Semykina and Wooldridge (2005) would be interesting to pursue but is beyond the scope of this paper.
} 
(2):

$$
\alpha_{i}=\zeta+\boldsymbol{g}_{i}^{\prime} \boldsymbol{\kappa}+r_{i}
$$

where $r_{i}$ is a random effect; defining

$$
\tilde{u}_{i t}=r_{i}+v_{i t}
$$

we assume in analogy to Equation (7) that

$$
\tilde{\boldsymbol{u}}_{i} \mid \boldsymbol{Z}_{i}, \zeta, \boldsymbol{g}_{i} \stackrel{i i d}{\sim} N\left(0, \sigma_{r}^{2} \iota \iota^{\prime}+\sigma_{v}^{2} \boldsymbol{I}\right)
$$

Note that the systematic component in $\alpha_{i}, \boldsymbol{g}_{i}$, consists of cross-sectional means over time, that is country-specific constants.

Clearly, the Mundlak (1978) and Semykina and Wooldridge (2005) fixed effects specification restricts the systematic variation of the country-specific effect to only arise through the vector of observables $\boldsymbol{g}_{i}$. This is a more restrictive specification of the fixed effect than often adopted in other panel data models, for example in the linear dynamic panel data literature. ${ }^{12}$

Let us use a similar decomposition as specified in Equation (15) for the country-specific effect in the participation selection equation also for the country-specific effect in the output growth (participation effects) equation (that is, Equation (1)):

$$
\mu_{i}=\psi+\boldsymbol{q}_{i}^{\prime} \boldsymbol{\phi}+\chi_{i}
$$

where $\chi_{i}$ is a random effect and $\boldsymbol{q}_{i}$ is a subset of $\boldsymbol{g}_{i}$; defining

$$
\tilde{\epsilon}_{i t}=\chi_{i}+e_{i t}
$$

we now also assume in analogy to Equation (8) that

$$
E\left(\tilde{\epsilon}_{i t} \mid \boldsymbol{Z}_{i}, \tilde{\boldsymbol{u}}_{i}, \psi, \boldsymbol{q}_{i}\right)=\tilde{\tau}_{1} \tilde{u}_{i t}+\tilde{\tau}_{2} \overline{\tilde{u}}_{i}
$$

Note that $\boldsymbol{g}$ is a subset of $\boldsymbol{q}$.

Under Equations (15) to (20), we therefore allow for a less restrictive

\footnotetext{
${ }^{12}$ See, for example, Binder, Hsiao, and Pesaran (2005) for an unrestricted formulation of fixed effects within a linear dynamic panel data model.
} 
specification of the country-specific effects than in Vella and Verbeek (1999), and capture a fixed effects specification in the spirit of Mundlak (1978) and Semykina and Wooldridge (2005), augmenting both the program selection equation, Equation (2), and the output growth equation, Equation (1), with the regressors in $\boldsymbol{q}_{i}$ and $\boldsymbol{g}_{i}$, but otherwise pursuing the estimation and inference procedure of Sub-Section 3.1. We will discuss the choice of elements in $\boldsymbol{q}_{i}$ in Section 6.

Finally, the null of the random effects specification of Sub-Section 3.1 can be tested against the fixed effects specification of this section by investigating whether $\boldsymbol{\kappa}=\mathbf{0}$ and $\boldsymbol{\phi}=\mathbf{0}$.

\section{Conditioning the Effect of IMF Loan Program Participation}

The fixed effects model of Section 3 still involves the restriction that the systematic differences in the output growth processes across participating countries can be captured through the country-specific effects and different realizations of the regressors in $d_{i t}$ and $\boldsymbol{x}_{i t}$. This is a rather strong assumption. To analyze the effects of IMF program participation, it clearly seems desirable to allow for systematic differences in these effects themselves across countries. To do so in a parsimonious form that also allows us to learn about the sources of the variations of the effects across countries, we consider here the conditional pooling (state dependence) approach of Binder and Offermanns (2008). This approach allows us to model the conditionality of the growth effects of IMF loan programs on a country's degree of program implementation or on its institutional quality with a minimal set of assumptions regarding the functional form of this conditionality. The approach consists of modelling the state dependence with flexible functional form polynomials, as a (cross-sectionally) homogeneous function of the relevant conditioning variable. Denoting the conditioning variable by $w_{i t}$ and the flexible functional form polynomial by $\theta\left(w_{i t}\right)$, Binder and Offermanns (2008) propose to specify $\theta\left(w_{i t}\right)$ using a parametric function of flexible form, and in particular choose Chebyshev polynomials as one specification of orthogonal polynomi- 
als:

$$
\theta\left(w_{i t}\right)=\sum_{s=0}^{\tau} \gamma_{s}^{(\theta)} c_{s}\left(w_{i t}\right)
$$

with the Chebyshev polynomials $c_{s}\left(w_{i t}\right)$ recursively defined as $c_{s+1}\left(w_{i t}\right)=$ $2 w_{i t} c_{s}\left(w_{i t}\right)-c_{s-1}\left(w_{i t}\right), s=1,2, \ldots, \tau, c_{0}\left(w_{i t}\right)=1, c_{1}\left(w_{i t}\right)=w_{i t}$, and where $\gamma_{s}^{(\theta)}, s=0,1, \ldots, \tau$, are coefficients that are homogeneous across countries. ${ }^{13}$

To condition an independent variable's effect, the variable may be multiplied with the Chebyshev polynomial $\theta\left(w_{i t}\right)$, and estimation can then be carried out as usual with the resultant augmented set of variables.

\section{Conditioning Variables}

Under the conditional pooling approach (some of) the model coefficients are a function of a conditioning variable. According to the IMF, "[c]onditionality refers to policies and actions that a borrowing member agrees to carry out as a condition for the use of IMF resources. The purpose of conditionality is to ensure assistance to members [...] in a manner that [...] establishes adequate safeguards for the temporary use of the IMF's resources." ${ }^{14}$ In practice, the IMF only disburses installments of funds agreed to in the loan program if the country initiates specific reforms, that is, complies with conditionality of the loan program. Hence, one way to model compliance with conditionality is to consider the ratio of loans actually drawn relative to loans originally agreed upon. ${ }^{15}$ Provided that the IMF consistently disburses funds only to countries that are sufficiently successful in advancing economic reforms, the loans-drawn-to-agreed ratio should be a useful proxy as to whether a country is successful in implementing the economic reforms advocated by the IMF.

We also consider a more direct measure of structural conditionality. Structural conditionality according to the IMF since the 1980s has involved changes in policy processes, legislation, and institutional reforms. ${ }^{16}$ In line

\footnotetext{
${ }^{13}$ Chebyshev polynomials belong to the class of orthogonal polynomials, and thus can address collinearity problems that could arise under $\tau>1$.

${ }^{14}$ See Fritz-Krockow and Ramlogan (2007), p. 25.

${ }^{15}$ This measure was initially suggested as a proxy for compliance with conditionality by Killick (1995)

${ }^{16}$ See Nsouli, Atoyan, and Mourmouras (2006).
} 
with this, the IMF is arguing that "the implementation of IMF-supported programs depends to a significant extent on the domestic political and institutional environment". ${ }^{17}$ By fostering institutional development, the IMF in effect acknowledges that efficient outcomes in market-oriented economies are most likely to occur when the non-market institutions are functioning well. Rodrik (2009) distinguishes between five types of institutions that allow markets to perform well: (i) private property rights give enterpreneurs the security of claiming the gains from investment and innovations; (ii) regulatory institutions prevent market failures that can arise from fraudulent behavior and incomplete information; (iii) institutions for macroeconomic stabilization are neccessary to alleviate shocks that hit the economy; (iv) institutions for social security render a market economy compatible with social coherence and stability; and (v) institutions of conflict management are neccessary to prevent social conflicts from creating uncertainty and diversion of ressources from economically productive activities. To capture a broad range of aspects of institutional quality, we construct for this paper an index incorporating measures of bureaucracy quality, absence of corruption, law and order, government stability, absence of ethnic tensions and internal conflicts, and add two further dimensions by also taking account of health (life expectancy) and educational attainment. The set up of the index is described in what follows. ${ }^{18}$ The index is constructed on the basis of the mean of the $j$-th country's index elements relative to the mean of the same index elements for a base-country year (the United States in 2000):

$$
\text { index }_{i t}=\frac{\sum_{s=1}^{m} s \text {-th } \text { variable }_{i t}}{\sum_{s=1}^{m} s \text {-th } \text { variable }_{\text {base-country, base-year }}},
$$

where $m$ denotes the number of variables that enter into the construction of the index. To be able to calculate this index, we replace missing observations using interpolated values. If for, say, country $i$ a time series is missing entirely, we proxy it via a "rank-matching" procedure: For each time period for country $i$, first a preliminary index is calculated on the basis of Equation (22) involving only those variables that are actually available for country $i$. We then also calculate the same preliminary index for all other countries

\footnotetext{
${ }^{17}$ See International Monetary Fund (2006).

${ }^{18} \mathrm{~A}$ listing including a description of all variables used for construction of our index is given in Appendix B.
} 
for time period $t$, excluding those variables that are completely missing for country $i$. Using these preliminary indices, we then calculate the period $t$ relative rank (that is, $\frac{\text { rank }_{\text {it }}}{\text { number of countriest }}$ ) of the preliminary index value of country $i$ among the set of all countries that can be considered for the preliminary index values in period $t$. We then proxy for time period $t$ the variable in country $i$ that is entirely missing with the value of that variable for which the period $t$ relative rank is closest to the relative rank calculated for country $i$ 's preliminary index for period $t$.

Finally, we impute those variables for which there are no observations either at the beginning or at the end of the series backward or forward, respectively, using the percentage changes of, again, a preliminary index that contains only the variables that are available for the country in the missing time period. At this point we then have for each country a balanced set of variables that can be used to calculate the index as outlined in Equation (22).

Our approach to index calculation ensures that there are no mean-shifts in the index if for a country the time series for some variable begins later or ends earlier than the time series for some other variables for that country. Our approach furthermore preserves all the information about the variation in the time series we exploit. It should be noted that due to the imputation procedure it is possible that an index value may become larger than one.

\section{Empirical Results}

We begin by discussing empirical results obtained when taking into account sample selection and regressor endogeneity by means of considering the fixed effects panel model without state dependence of effects, as outlined in SubSection 3.1. ${ }^{19}$ The selection equation, Equation (2) is a fixed effects Tobit

\footnotetext{
${ }^{19}$ The set of regressors for all equations was chosen on the basis of the Akaike Information Criterion (AIC). Since the AIC turned out to always select the fixed effects specification, in what follows we focus our discussion on the fixed effects model. Potential candidates for the Mundlak variables, $g_{i}$ and $q_{i}$, were a country's fertility rate, freedom of the press, freedom status of society, economic proximity to the U.S. and economic proximity to major Europe. Results for the random effects specification are provided as robustness check in Appendix D. Potential candidates for $\boldsymbol{z}_{i t}$ and $\boldsymbol{x}_{i t}$ were a country's cumulative number of years in IMF loan programs, quota share at the IMF, staff share at the IMF, political proximity to the U.S., political proximity to major Europe, reserve position, current account position, trade openness, democracy index rating, investment share of GDP, Government share of GDP, and inflation.
} 
model, as the loan-quota ratio is left-censored at zero. It contains country years with and without participation in IMF loan programs. Note that when later we turn to considering state dependence of effects, the estimated models involve different sets of observations than considered here, depending on the conditioning variable chosen. ${ }^{20}$ Table 1 displays our estimation results when estimating Equation (2), with the full set of observations available.

Table 1: Participation Selection Equation, FE Tobit Model

\begin{tabular}{|l|c|}
\hline Independent Variables & Coefficients \\
\hline Investment Share & $-1.686^{* *}$ \\
& {$[2.579]$} \\
\hline Inflation & $-0.027^{* *}$ \\
& {$[2.771]$} \\
\hline Reserves & -0.053 \\
& {$[0.374]$} \\
\hline Government Share & 0.432 \\
& {$[1.014]$} \\
\hline Current Account & -0.077 \\
& {$[0.207]$} \\
\hline Openness & -0.094 \\
& {$[0.859]$} \\
\hline Democracy Index & $-0.030^{* *}$ \\
& {$[2.371]$} \\
\hline Number of Years under IMF Programs & $0.020^{* * *}$ \\
& {$[4.358]$} \\
\hline Mean Fertility Rate & $0.556^{*}$ \\
& {$[1.875]$} \\
\hline Mean Economic Proximity to Major Europe & $-0.132^{* *}$ \\
& {$[2.032]$} \\
\hline \hline Number of Observations for the selection equation: & 1640 \\
\hline Note: Estimation results are obtained by estimating Equation (2), augmented with the Mundlak variables
\end{tabular}

capturing fixed effects. The dependent variable is the loan-quota ratio. The F-test of joint significance of the Mundlak variables is significant at the $5 \%$ significance level. $t$-statistics are displayed in square brackets underneath the coefficient estimates. A “*” indicates significance at the $10 \%$ level, a "**" indicates significance at the $5 \%$ level and a "***" indicates significance at the $1 \%$ level. The regression uses annual data, the sample extends from 1975 to 2005 and the number of countries considered is 68. A description of all variables used is provided in Appendix B.

As can be seen from Table 1, the estimated coefficients on the investment share, inflation, measure of democracy and mean economic proximity to Major Europe are significantly negative. If the investment share or the inflation rate decline by one percentage point, then the ratio of IMF lending to a country's quota increases by 1.686 or 0.027 percentage points,

\footnotetext{
${ }^{20}$ One of the conditioning variables, the (growth rate of the) index of institutional quality, is available only for a sub-set of the observations in our sample. When using this sub-set of observations the results of the selection equation do not change qualitatively, however.
} 
respectively. ${ }^{21}$ If the measure for democracy increases by one basis point or the mean economic proximity to Major Europe increases by one percentage point, then the loan-quota ratio decreases by 3 or 0.132 percentage points, respectively. The effect of a country's mean fertility rate and the number of years a country has been under IMF loan programs are significantly positive. If the mean fertility rate increases by one percentage point or the number of years under IMF loan programs increases by one year, then the loan-quota ratio increases by 0.556 and 2 percentage points, respectively.

Figure 1 displays the marginal effects (red curve) of the significant variables from Table 1 as well as the corresponding one-standard deviation (green) and two-standard deviation (blue) bands.

The residual obtained from estimating the participation selection equation can be used to generate correction terms that, as described in SubSection 3.1, in addition to correcting for sample selection also correct for endogeneity when estimating the effects of changes in the loan-quota ratio on the output growth of countries participating in IMF loan programs. Table 2 displays our estimation results for the fixed effects participation effects model (without state dependence) of Sub-Section 3.1, using the growth rate of real GDP per capita as the dependent variable and the IMF loan-quota ratio, ${ }^{22}$ as well as a set of explanatory variables as independent variables. ${ }^{23}$ The estimated coefficient on the investment share is significantly positive. An increase of the investment share by one percentage point increases a

\footnotetext{
${ }^{21}$ Note that differentiating the latent variable (denoted here generically as $y^{*}$ ) with respect to the independent variable (denoted here generically as $x$, entering into the Tobit model with a coefficient of $\beta$ ), we of course have

$$
\frac{\partial E\left(y^{*} \mid x\right)}{\partial x}=\beta
$$

The marginal effect for the observed dependent variable needs to be corrected for censoring, multiplying $\beta$ with the probability that the loan-quota ratio is strictly positive. All reported effects are average marginal effects evaluated at the independent variables' sample means.

${ }^{22}$ The IMF loan-quota ratio captures the average, on a monthly basis, of funds agreed upon in all loan programs (SBA, EFF, SAF, ESAF/PRGF) divided by the country's quota at the IMF. Note that Dreher (2006) only covers those arrangements that have been active for at least five months in a given calendar year. Our results do not change if we adjust the loan-quota ratio accordingly. Similar to Vreeland (2003), we consider consecutive agreements with the IMF as part of the same spell, since governments most of the time have several consecutive agreements with the IMF. A description of all variables used is provided in Appendix B.

${ }^{23}$ All standard errors reported in the following tables are corrected for first-step sampling uncertainty affecting second-step inference. See also Appendix A.
} 
Figure 1: Marginal Effects for Participation Selection Equation

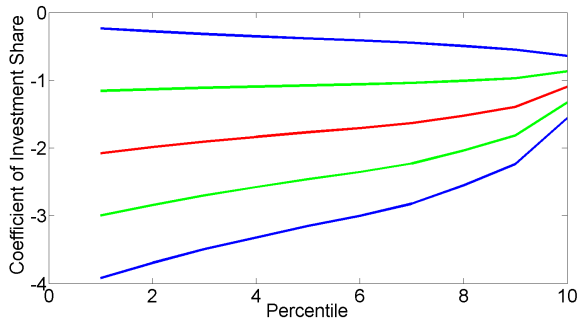

(a) Investment share

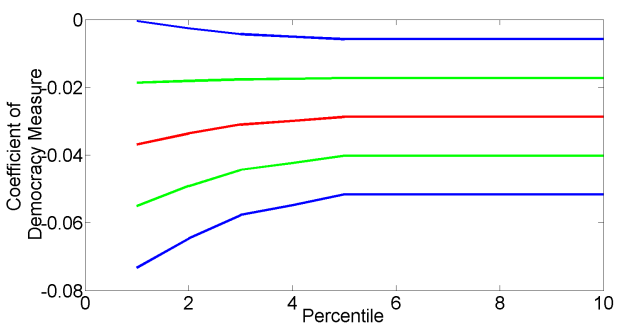

(c) Democracy

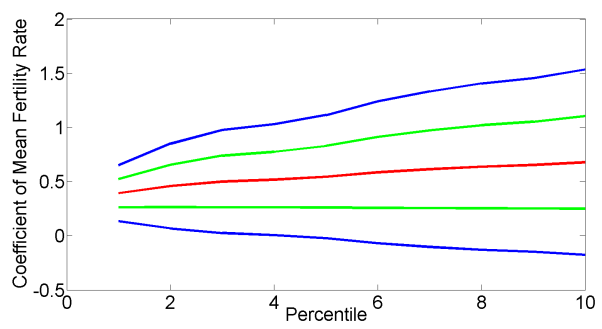

(e) Mean fertility rate

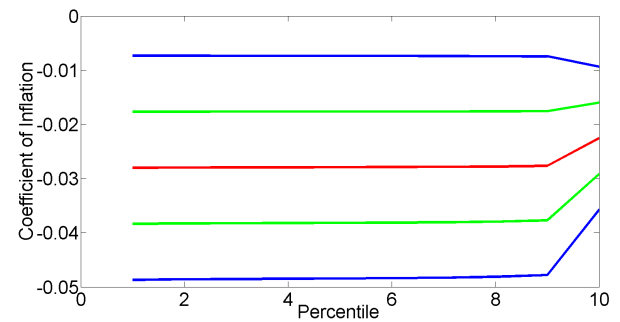

(b) Inflation

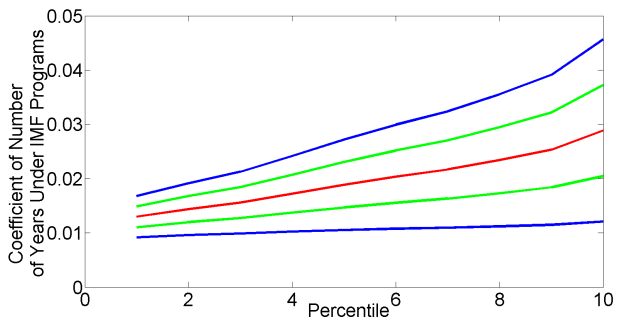

(d) Number of years under IMF programs

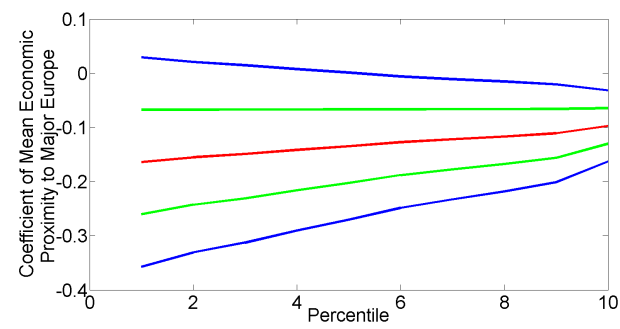

(f) Mean economic proximity to Major Europe

country's growth rate of real GDP per capita by 0.09 percentage points. The coefficients on inflation and the mean of a country's fertility rate are significantly negative. An increase of inflation by one percentage point and an increase of the mean fertility rate by one unit lead to a decrease of the real GDP per capita growth rate by 0.003 and 0.035 percentage points, respectively.

Two further issues are worth noting: First, $\tau_{1}$ (not displayed in the table) is significant at the $10 \%$ level, providing evidence for a sample selection mechanism. Second, the coefficient on the loan-quota ratio is positive but not significant. ${ }^{24}$

\footnotetext{
${ }^{24}$ When estimating the participation effects equation without the sample selection cor-
} 
Table 2: Participation Effects Equation, FE Model without State Dependence

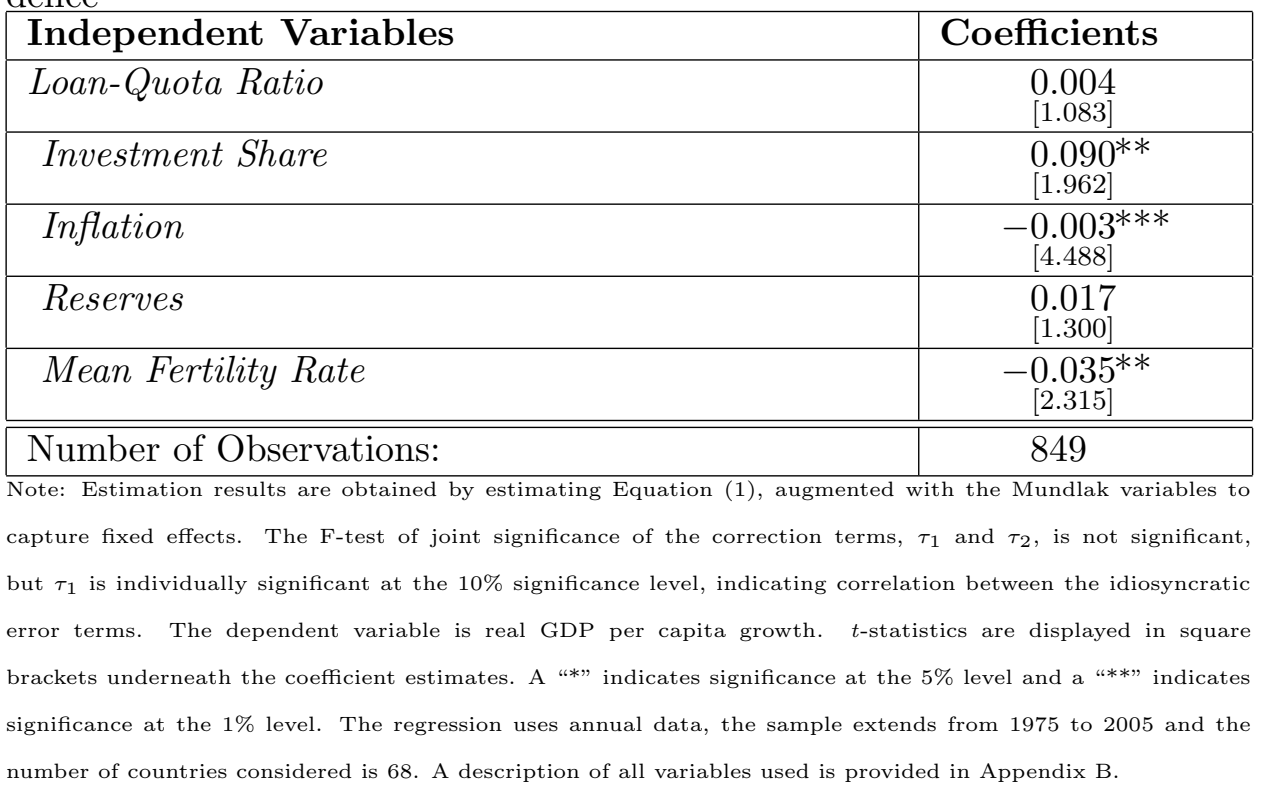

To address the issue of heterogeneity bias in the loan program participation effects estimates when state dependence of the effects is ignored, in our next step of analysis we condition the effects of the loan-quota ratio on output growth on the amount-drawn-to-amount-agreed ratio, which, as discussed in Section 5, may serve as a useful proxy for measuring state dependence of effects. Taking into account such state dependence may also on its own contribute to alleviating the endogeneity problem: One may expect that a higher degree of compliance with conditionality causes higher (lower) output growth if the reforms implemented promote higher (lower) output growth. However, output growth should have a negligable effect on compliance with conditionality. It appears sensible to conjecture that lower output growth raises a country's willingness to accept painful economic reforms. In this case, lower output growth should be associated with a higher degree of compliance. In any case, the amount-drawn-to-amount-agreed ratio and real GDP per capita growth in our data set feature a correlation of -0.05 only.

Table 3 provides our estimation results when using Chebyshev polynomi-

rection terms (which we can do for a total of 938 observations), then the coefficient on the loan-quota ratio has negative sign $(-0.003)$, with a t-statistic of -1.522 . 
als of order one and the amount-drawn-to-amount-agreed ratio as capturing state dependence.

Table 3: Participation Effects Equation, FE Model

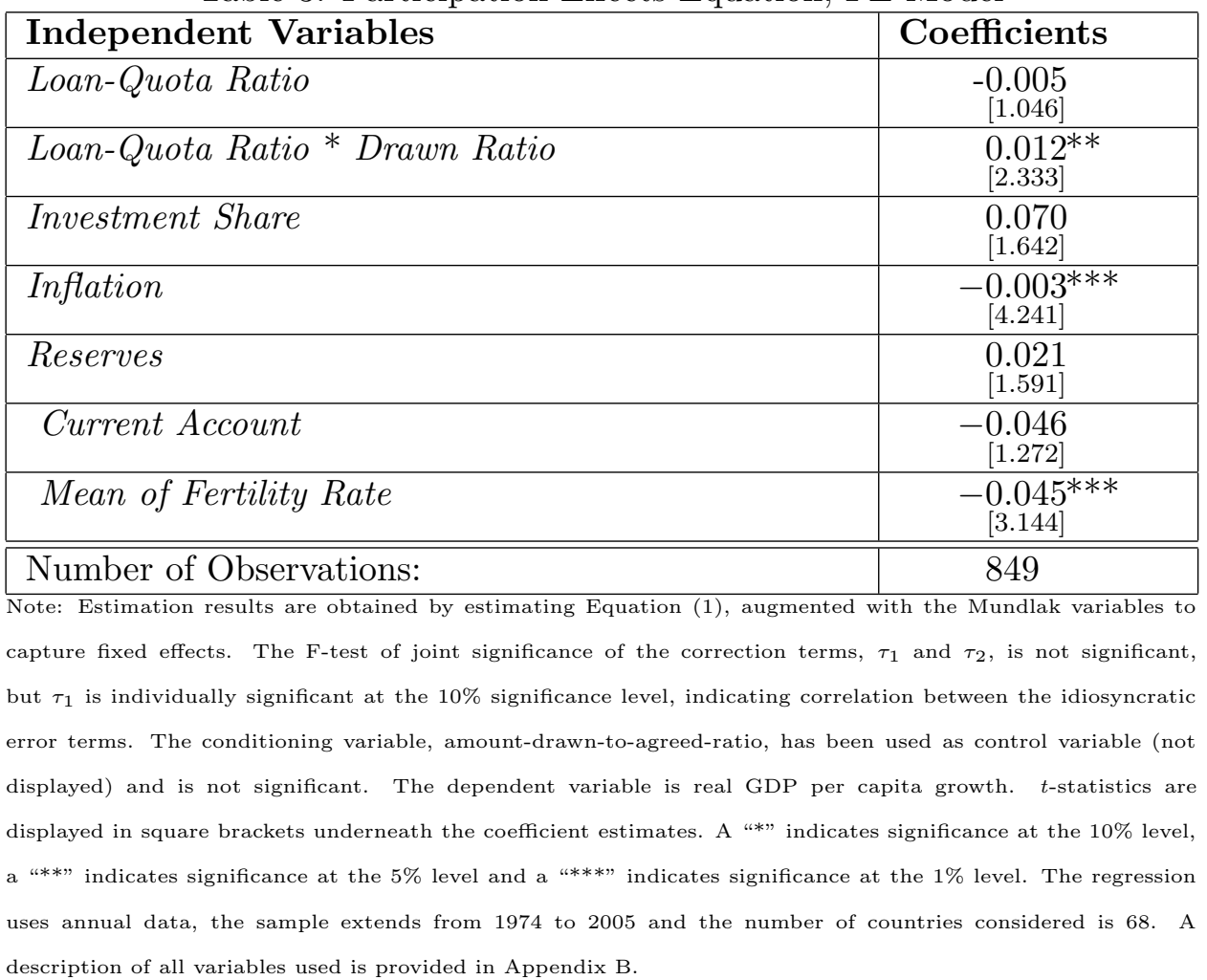

Conditioning the output growth effects of the loan-quota ratio on the proxy for compliance with conditionality has a considerable effect on the estimation results: If a participating country were not to comply with conditionality at all, the effect of loan program participation on output growth is negative. An increase in the loan-quota ratio by 1 percentage point lowers the growth rate of real GDP per capita by 0.005 percentage points. (If such a country does not receive any funds from the IMF, because it does not set in effect the required reforms, the output growth effect obviously would be zero.) However, the higher the compliance ratio, the smaller in absolute terms the negative output growth effect of the loan-quota ratio. If the compliance ratio is larger than $42 \%$, then the effect of IMF program participation turns positive. ${ }^{25}$ If all funds originally agreed upon are drawn,

\footnotetext{
${ }^{25}$ Note that this ratio is sizeably smaller than in Killick (1995), who sets a threshold value for successful IMF program implementation at $80 \%$, arguing that this cut-off point
} 
Figure 2: Effect of IMF Loan Size Conditional on Actual Degree of Program Implementation, Annual Data, 1975 - 2005, 68 Countries.

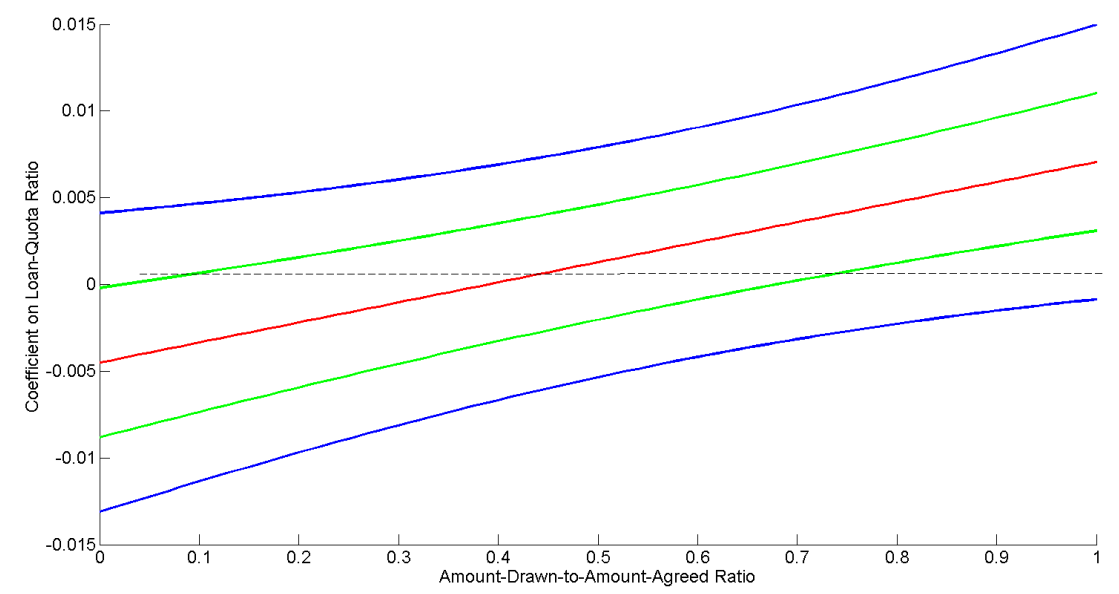

that is, there is full compliance with IMF conditionality, then an increase of the loan-quota ratio by 1 percentage point leads to an increase of real GDP per capita growth by 0.007 percentage points. These results are in line with IMF arguments stressing that compliance with conditionality is important for the success of IMF loan programs. Figure 2 plots the coefficient on the loan-quota ratio conditional on the amount-drawn-to-amount-agreed-ratio (red curve) with the one standard deviation (green) and two standard deviation (blue) bands. The effect of the IMF loan-quota ratio at a $10 \%$ level turns significantly positive from an amount-drawn-to-amount-agreed ratio of 0.73 upwards.

To provide a different measure of quantification of the output growth effects of IMF loan programs, Table 4 displays the average contribution of the various regressors to a country's real GDP per capita growth net of individual-specific effects, as implied by the state-dependent panel model in Table 3:

is closely associated with successful program implementation based on a survey between 1980 and 1992. 
Table 4: Growth Accounting, Annual Data, 1975 - 2005, 73 Countries.

\begin{tabular}{|l|c|c|}
\hline Variables & Mean Effect & Contrib. in \% \\
\hline Loan-Quota Ratio & -0.005 & -30.39 \\
\hline Loan-Quota Ratio * Drawn Ratio & 0.006 & 37.88 \\
\hline Investment Share & 0.008 & 49.98 \\
\hline Inflation & -0.001 & -7.94 \\
\hline Reserves & 0.006 & 36.70 \\
\hline Current Account & 0.002 & 13.78 \\
\hline \hline Sum & 0.015 & 100.00 \\
\hline
\end{tabular}

The overall contribution of the loan-quota ratio to real GDP per capita growth net of individual-specific effects is equal to $7.49 \%$. The investment share contributes most to a participating country's real GDP per capita growth, at almost $50 \%$.

To investigate the state dependence of the output growth effects of IMF program participation on a country's institutional quality directly, we next use our index of institutional quality as described in Section 5. Since structural conditionality is measured in changes by the IMF, we include the index of institutional quality in percentage changes ("institutional development") as our conditioning variable.

Table 5 displays results when using Chebyshev polynomials of order one and institutional development as the conditioning variable.

Conditioning the effect of the loan-quota ratio on institutional development yields significant results: If a country cannot improve its institutional quality, the effect of program participation on output growth is negative: An increase of the loan-quota ratio by 1 percentage point lowers the growth rate of real GDP per capita by 0.004 percentage points. At the same time, the estimated coefficient increases systematically with the magnitude of institutional development. Figure 3 displays the coefficient on the loan-quota ratio conditional on the progress in institutional development. If the institutional development progress exceeds 0.12 , the effect of IMF loan program participation on output growth turns significantly positive at the $5 \%$ level.

Table 6 displays the average contribution of the various regressors to a country's real GDP per capita growth net of individual-specific effects, as implied by the state-dependent panel model in Table 5 .

Having analyzed the effect of a country's participation in IMF loan pro- 
Table 5: Participation Effects Equation, FE Model

\begin{tabular}{|l|c|}
\hline Independent Variables & Coefficients \\
\hline Loan-Quota Ratio & 0.004 \\
& {$[1.024]$} \\
\hline Loan-Quota Ratio $^{*}$ Institutional Development & $0.049^{* *}$ \\
& {$[2.002]$} \\
\hline Investment Share & 0.070 \\
& {$[0.865]$} \\
\hline Inflation & $-0.003^{* * *}$ \\
& {$[4.257]$} \\
\hline Democracy & 0.002 \\
& {$[1.059]$} \\
\hline Mean Fertility Rate & $-0.038^{* *}$ \\
\hline Number of Observations: & {$[2.070]$} \\
\hline Note: Estimation results are obtained by estimating Equation (1), augmented with the Mundlak variables to
\end{tabular}

capture fixed effects. The F-test of joint significance of the correction terms, $\tau_{1}$ and $\tau_{2}$, is not significant. The

conditioning variable, institutional development, has also been considered as a control variable (not displayed)

and is not significant. The dependent variable is real GDP per capita growth. $t$-statistics are displayed in square brackets underneath the coefficient estimates. A “*” indicates significance at the $10 \%$ level, a "**" indicates significance at the $5 \%$ level and a "***" indicates significance at the $1 \%$ level. The regression uses annual data, the sample extends from 1975 to 2005 and the number of countries considered is 60 . A description of all variables used is provided in Appendix B.

grams on its output growth, we next turn our focus to analyses of counterfactuals and intertemporal effects involving IMF loan programs. To get an idea about the magnitude of the effect of IMF program participation on countries' output growth, Tables 7 and 8 display counterfactual analyses for the panel models reported in Tables 3 and 5 .

Table 7 reports that during participation in IMF loan programs countries between 1975 and 2005 had on average a real GDP per capita growth rate of $0.56 \%$. The predicted value of this growth rate using the coefficients from the sample estimated only with country years under participation equals this

Table 6: Growth Accounting, Annual Data, 1975 - 2005, 65 Countries

\begin{tabular}{|l|c|c|}
\hline Variables & Mean Effect & Contrib. in \% \\
\hline Loan-Quota Ratio & 0.004 & 19.89 \\
\hline Loan-Quota Ratio * Instit. Dev. & 0.001 & 2.33 \\
\hline Investment Share & 0.007 & 35.11 \\
\hline Inflation & -0.001 & -6.06 \\
\hline Democracy & 0.010 & 48.73 \\
\hline \hline Sum & 0.021 & 100.00 \\
\hline
\end{tabular}


Figure 3: Coefficient of Loan-Quota Ratio Conditioned on a Country's Progress in Institutional Development, Annual Data, 1975 - 2005, 60 Countries.

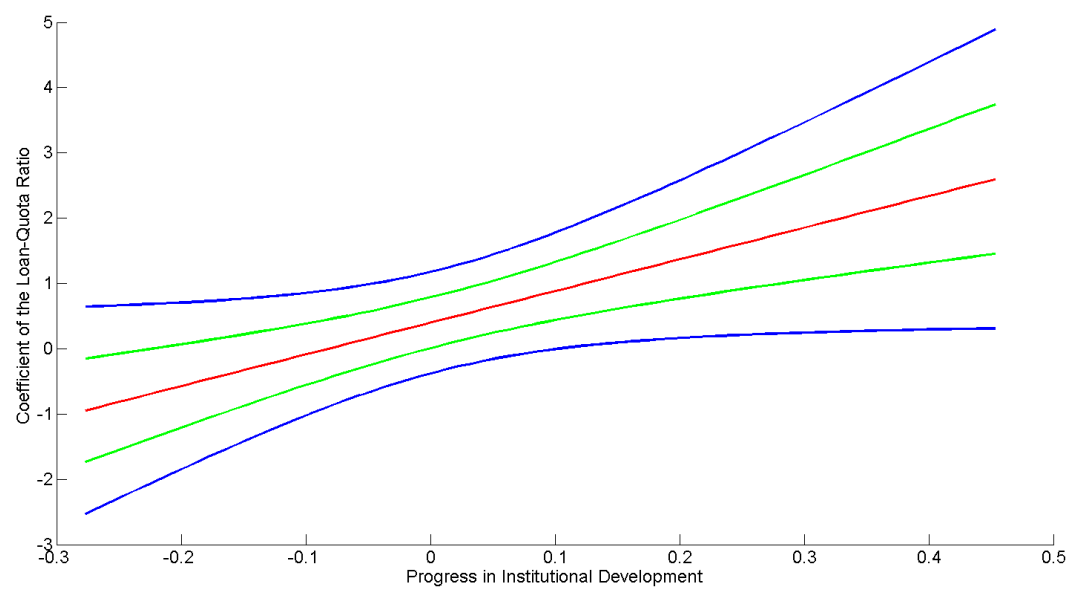

Table 7: Counterfactual Analysis, 1975 - 2005, Participating and NonParticipating Countries, Conditioning with the Amount-Drawn-to-AmountAgreed Ratio, FE Specification

\begin{tabular}{|l|c|c|c|c|}
\hline Country years & Actual $^{a)}$ & Predicted $^{b)}$ & Predicted $^{c)}$ & Predicted $^{d)}$ \\
\hline Particip. & $0.56 \%$ & $0.56 \%$ & $0.45 \%$ & $1.40 \%$ \\
\hline Non-Particip. & $1.63 \%$ & - & $2.03 \%$ & $1.63 \%$ \\
\hline
\end{tabular}

a) Actual average growth.

b) Coefficient estimates used to compute the counterfactual are taken from the model specification involving only country years with participation in IMF loan programs.

c) Coefficient estimates used to compute the counterfactual are taken from the model specification involving only country years with participation in IMF loan programs. The independent variable loan-quota ratio is always set to zero.

d) Coefficient estimates used to compute the counterfactual are taken from the model specification involving only country years without participation in IMF loan programs. 
Table 8: Counterfactual Analysis, 1975 - 2005, Participating and NonParticipating Countries, Conditioning with the Progress in Institutional Development, FE Specification

\begin{tabular}{|l|c|c|c|c|}
\hline Country years & Actual $^{a)}$ & Predicted $^{b)}$ & Predicted $^{c)}$ & Predicted $^{d)}$ \\
\hline Particip. & $0.52 \%$ & $0.52 \%$ & $0.05 \%$ & $1.43 \%$ \\
\hline Non-Particip. & $1.53 \%$ & - & $2.08 \%$ & $1.53 \%$ \\
\hline
\end{tabular}

a) Actual average growth.

b) Coefficient estimates used to compute the counterfactual are taken from the model specification involving only country years with participation in IMF loan programs.

c) Coefficient estimates used to compute the counterfactual are taken from the model specification involving only country years with participation in IMF loan programs. The independent variable loan-quota ratio is always set to zero.

d) Coefficient estimates used to compute the counterfactual are taken from the model specification involving only country years without participation in IMF loan programs.

$0.56 \%$, while the fitted value using the same coefficients, but counterfactually setting the loan-quota ratio to zero, amounts to $0.45 \%$. The predicted value using the coefficients from the sample estimated only with country years not under participation amounts to $1.40 \%$. Non-participating countries actually had on average a real per capita GDP growth of $1.63 \%$. The predicted value using the coefficients from the sample estimated only with country years not under participation amounts to $1.63 \%$ while the fitted value using the coefficients from the sample estimated only with countryyears under participation, but counterfactually setting the loan-quota ratio always to zero, amounts to $2.03 \%$.

Three points are worth highlighting here. First, the second column of Table 7 highlights the fact that country years under IMF loan participation are times of (economic) crises. On average, countries had much lower output growth during years of participation in IMF loan programs. For this reason, it is imperative to properly capture the direction of causation in growth regressions involving development aid. Second, countries in economic crisis are, on average, better off when turning to the IMF and participating in IMF loan programs. The annual percentage gain amounts to $0.11 \%$ real per capita GDP growth per year. Nevertheless, as our results make clear, it is important for a country to comply with conditionality and improve upon its institutional quality. Third, according to our counterfactuals, countries that participated in IMF loan programs would have had an average growth 
rate of $1.40 \%$ had they not participated. This number is almost three times as high as their actual average growth rate, and thus seems rather unrealistic. Our counterfactuals thus appear to provide evidence in favor of the presumption underlying our estimation strategy that countries entering IMF loan programs in times of crises have fundamentally different growth regimes than those countries that do not.

To learn more about the dynamic effects of IMF loan-program participation on a country's output growth, we finally turn to estimating the country's growth rates between $t-1$ and $t-1+i, i=1,2, \ldots, 5$, that can be attributed to IMF loan participation in year $t .{ }^{26}$ Figures 4 and 5 display the intertemporal effects when taking the optimal specification of the fixed effects model with the amount-drawn-to-amount-agreed ratio or the progress in institutional development as conditioning state variable, respectively.

Figure 4: Intertemporal Effect of the Loan-Quota Ratio on a Country's Output Growth in the FE Model with Amount-Drawn-to-Amount-Agreed Ratio as Conditioning Variable.

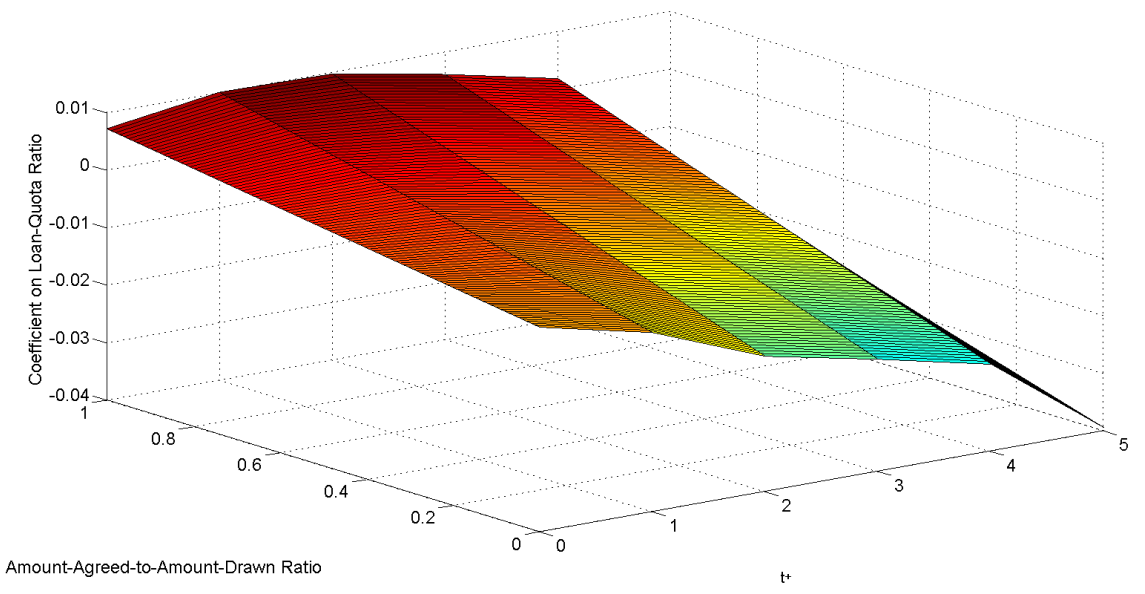

Tables 9 and 10 display the corresponding coefficients and their significance levels for all time periods.

The output growth effects of participation in IMF loan programs are significant for up to three years after participation in an IMF loan program. For all time periods the output growth effects of participation in IMF loan

\footnotetext{
${ }^{26}$ Note that it is not yet possible to use a dynamic model structure, in particular in the growth equation, in our sample selection model.
} 
Figure 5: Intertemporal Effect of the Loan-Quota Ratio on a Country's Output Growth in the FE Model with Progress of Institutional Development as Conditioning Variable.

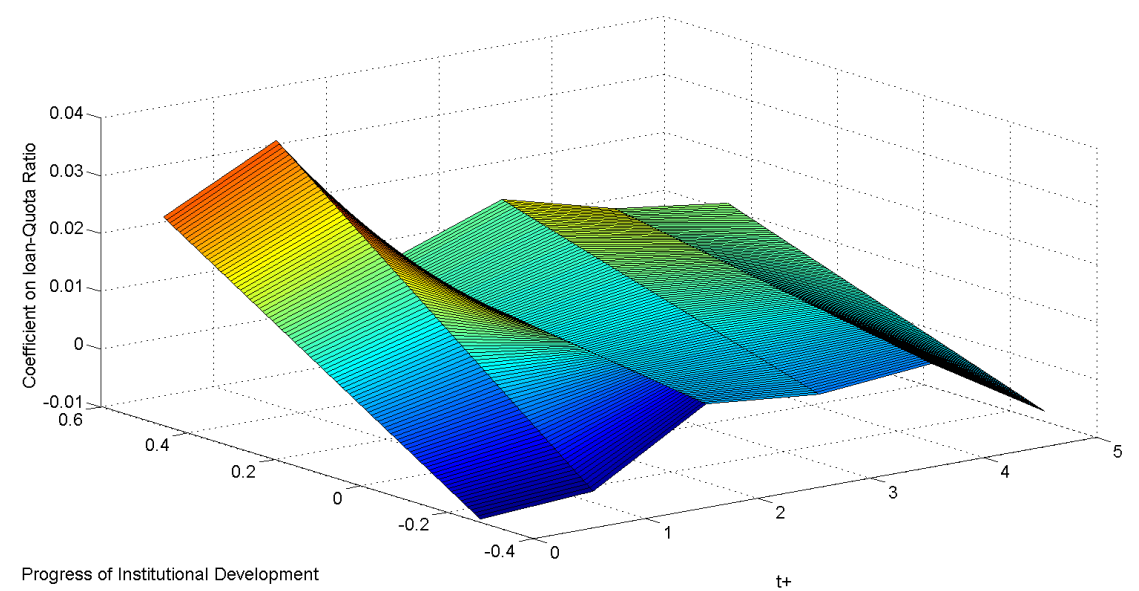

Table 9: Coefficients of the Loan-Quota Ratio in the FE Model in an Intertemporal Perspective with the Amount-Drawn-to-Amount-Agreed Ratio as Conditioning Variable

\begin{tabular}{|c|c|c|}
\hline Dep. Variable & Loan-Quota Ratio & Loan-Quota Ratio*Drawn Ratio \\
\hline$\frac{y_{t}-y_{t-1}}{y_{t}}$ & -0.005 & $0.012^{* *}$ \\
\hline$\frac{y_{t+1}-y_{t-1}}{y_{t+1}}$ & {$[1.046]$} & {$[2.333]$} \\
\hline$\frac{y_{t+2}-y_{t-1}}{y_{t+2}}$ & -0.009 & $0.019^{*}$ \\
\hline$\frac{y_{t+3}-y_{t-1}}{y_{t+3}}$ & $-0.863]$ & {$[1.923]$} \\
\hline$\frac{y_{t+4}-y_{t-1}}{y_{t+4}}$ & -0.017 & $0.026^{* *}$ \\
\hline$\frac{y_{t+5}-y_{t-1}}{y_{t+5}}$ & -0.021 & {$[2.166]$} \\
\hline Note: T-statistics are displayed in square brackets. A (**) indicates significance at the $10 \%$ level and a “**"
\end{tabular}

indicates significance at the $5 \%$ level. 
Table 10: Coefficients of the Loan-Quota Ratio in the FE Model in an Intertemporal Perspective with the Progress in Institutional Development as Conditioning Variable

\begin{tabular}{|c|c|c|}
\hline Dep. Variable & Loan-Quota Ratio & Loan-Quota Ratio*Instit. Dev. \\
\hline$\frac{y_{t}-y_{t-1}}{y_{t}}$ & 0.004 & $0.049^{* *}$ \\
\hline$\frac{y_{t+1}-y_{t-1}}{y_{t+1}}$ & {$[1.024]$} & {$[2.002]$} \\
\hline$\frac{y_{t+2}-y_{t-1}}{y_{t+2}}$ & 0.008 & $0.060^{*}$ \\
\hline$\frac{y_{t+3}-y_{t-1}}{y_{t+3}}$ & $0.981]$ & {$[1.737]$} \\
\hline$\frac{y_{t+4}-y_{t-1}}{y_{t+4}}$ & {$[0.401]$} & 0.110 \\
\hline$\frac{y_{t+5}-y_{t-1}}{y_{t+5}}$ & 0.008 & {$[0.265]$} \\
\hline Note: T-statistics are displayed in square brackets. A “*” indicates significance at the $10 \%$ level and a “**" & 0.023 \\
\hline
\end{tabular}

indicates significance at the $5 \%$ level.

programs are more favorable if a country complies with conditionality / improves on institutional development.

\section{Conclusion}

Through modelling conditionality of the output growth effects of IMF program participation, in this paper we have shed light on what appears to be a major reason as to why previous empirical studies have arrived at mixed results, ranging from positive output growth effects to no effects to negative effects from IMF program participation. Allowing the effects of IMF program participation to vary systematically with the degree of program implementation or an index of institutional development, we find that there are significant positive effects of IMF program participation on a country's output growth only if the IMF programs are implemented to a sufficient degree or if the program participation is coupled with sufficient progress in improving institutional quality.

With regards to the magnitude of these output growth effects, our growth accounting calculations provide evidence that IMF loans have a sizeable impact. Their output growth effect, in absolute size, is larger than that of inflation, for example, though much smaller than that of investment in physical capital.

Our counterfactual analysis provides evidence that countries participat- 
ing in IMF loan programs would on average have had lower output growth, had they not participated in IMF loan programs. The higher the degree of program implementation and improvement in institutional quality, the higher the potential gains from participating in IMF loan programs. We also find that output growth effects of IMF program participation are significant for up to three years after program participation, and are significantly positive if participating countries comply with conditionality. Countries that decide to turn to the IMF for funding appear well advised to comply with IMF conditionality and to make every effort in improving their institutional environment. 


\section{Appendix A: Computation of Conditional Expecta- tions and of Standard Errors}

In this appendix we first discuss the computation of the conditional expectation in Equation (10) needed to correct the output growth equation, that is Equation (1), under the random effects specification for sample selection bias, while also allowing for endogeneity of $d_{i t} .{ }^{27}$ The conditional expectation of $v_{i t}$ given $\boldsymbol{Z}_{i}, \boldsymbol{d}_{i}$, and $\alpha_{i}$ on the right hand side of Equation (2) is calculated as follows:

$E\left(v_{i t} \mid \boldsymbol{Z}_{i}, \boldsymbol{d}_{i}, \alpha_{i}\right)=\left[d_{i t}-\left(\alpha_{i}+\boldsymbol{z}_{i t}^{\prime} \boldsymbol{\gamma}\right)\right] 1_{\left(d_{i t}>0\right)}-\left(\sigma_{v} \frac{\phi\left(\frac{\alpha_{i}+\boldsymbol{z}_{i t}^{\prime} \boldsymbol{\gamma}}{\sigma_{v}}\right)}{\Phi\left(\frac{-\alpha_{i}-\boldsymbol{z}_{i t}^{\prime} \boldsymbol{\gamma}}{\sigma_{v}}\right)}\right) 1_{\left(d_{i t}=0\right)}$,

where $\phi$ and $\Phi$ denote the standard normal probability and cumulative density functions, respectively, and $1(\cdot)$ denotes the indicator function.

Using this expression, the conditional expectation of $u_{i t}$ given $\boldsymbol{Z}_{i}$ and $\boldsymbol{d}_{i}$, Equation (10), can be obtained as:

$$
\begin{aligned}
E\left[u_{i t} \mid \boldsymbol{Z}_{i}, \boldsymbol{d}_{i}\right]= & \int\left\{\alpha_{i}+\left[d_{i t}-\left(\alpha_{i}+\boldsymbol{z}_{i t}^{\prime} \boldsymbol{\gamma}\right)\right] 1_{\left(d_{i t}>0\right)}-\sigma_{v} \frac{\phi\left(\frac{\alpha_{i}+\boldsymbol{z}_{i t}^{\prime} \boldsymbol{\gamma}}{\sigma_{v}}\right)}{\Phi\left(\frac{-\alpha_{i}-\boldsymbol{z}_{i t}^{\prime} \boldsymbol{\gamma}}{\sigma_{v}}\right)} 1_{\left(d_{i t}=0\right)}\right\} \\
& \cdot \frac{\left[\prod_{t=1}^{T} \Phi\left(\frac{-\alpha_{i}-\boldsymbol{z}_{i t}^{\prime} \boldsymbol{\gamma}}{\sigma_{v}}\right) 1_{\left(d_{i t}=0\right)} \frac{1}{\sigma_{v}} \phi\left(\frac{d_{i t}-\alpha_{i}-\boldsymbol{z}_{i t}^{\prime} \boldsymbol{\gamma}}{\sigma_{v}}\right) 1_{\left(d_{i t}>0\right)}\right] \frac{1}{\sigma_{\alpha}} \phi\left(\frac{\alpha_{i}}{\sigma_{\alpha}}\right)}{\int\left[\prod_{t=1}^{T} \Phi\left(\frac{-\alpha_{i}-\boldsymbol{z}_{i t}^{\prime} \boldsymbol{\gamma}}{\sigma_{v}}\right) 1_{\left(d_{i t}=0\right)} \frac{1}{\sigma_{v}} \phi\left(\frac{d_{i t}-\alpha_{i}-\boldsymbol{z}_{i t}^{\prime} \boldsymbol{\gamma}}{\sigma_{v}}\right) 1_{\left(d_{i t}>0\right)}\right] \frac{1}{\sigma_{\alpha}} \phi\left(\frac{\alpha_{i}}{\sigma_{\alpha}}\right) d \alpha_{i}} d \alpha_{i} .
\end{aligned}
$$

When obtaining standard errors for the estimates of the parameters of the output growth equation under the two-step procedure of Section 3, the sampling uncertainty that has entered the construction of the correction factors $\hat{u}_{i t}$ and $\hat{\bar{u}}_{i}$ needs to be observed. The following estimator of the

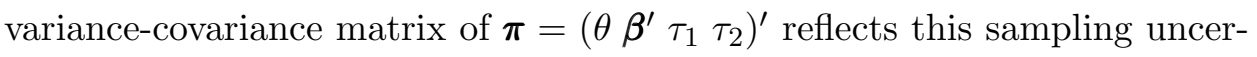
tainty:

$$
\hat{\operatorname{Var}_{N}}=\frac{1}{N} \hat{\boldsymbol{G}}_{N}^{-1}\left(\hat{\boldsymbol{V}}_{N}+\hat{\boldsymbol{D}}_{N} \hat{\boldsymbol{W}}_{N} \hat{\boldsymbol{D}}_{N}^{\prime}\right) \hat{\boldsymbol{G}}_{N}^{-1},
$$

\footnotetext{
${ }^{27}$ Note that the conditional expectation $E\left(\tilde{u}_{i t} \mid \boldsymbol{Z}_{i}, \boldsymbol{d}_{i}\right)$ arising under the fixed effects specification can be computed in analogous fashion, and thus need not be considered separately.
} 
where $\hat{\boldsymbol{W}}_{N}=\hat{\operatorname{Var}}_{N}(\hat{\gamma})$,

$$
\begin{gathered}
\hat{\boldsymbol{G}}_{N}=\frac{1}{N} \sum_{i=1}^{N} \boldsymbol{R}_{i}^{\prime} \boldsymbol{R}_{i}, \\
\hat{\boldsymbol{V}}_{N}=\frac{1}{N} \sum_{i=1}^{N} \boldsymbol{R}_{i}^{\prime} \hat{\boldsymbol{e}}_{i} \hat{\boldsymbol{e}}_{i}^{\prime} \boldsymbol{R}_{i}, \\
\hat{\boldsymbol{D}}_{N}=\left.\frac{1}{N} \sum_{i=1}^{N} \boldsymbol{R}_{i}^{\prime} \frac{\partial\left[\left(\hat{\boldsymbol{u}}_{i} \hat{\bar{u}}_{i} \boldsymbol{\iota}\right) \hat{\boldsymbol{\tau}}\right]}{\partial \boldsymbol{\gamma}}\right|_{\boldsymbol{\gamma}=\hat{\boldsymbol{\gamma}}}
\end{gathered}
$$

with

$$
\begin{gathered}
\boldsymbol{R}_{i}=\left(\boldsymbol{d}_{i} \boldsymbol{x}_{i}^{\prime} \hat{\boldsymbol{u}}_{i} \hat{\bar{u}}_{i} \iota\right), \\
\boldsymbol{\tau}=\left(\tau_{1} \tau_{2}\right)^{\prime},
\end{gathered}
$$

and $\iota$ is again a vector of ones of size $T_{i}$. Note that if $\tau_{2}=0$ is imposed in the estimation, then it appears sensible to also impose that $\hat{\boldsymbol{e}}_{i} \hat{\boldsymbol{e}}_{i}^{\prime}$ is a diagonal matrix (reflecting that $e_{i t}$ is restricted to be intertemporally uncorrelated).

Computation of the standard errors of the growth equation parameter estimates under the fixed effects specification can proceed in analogy to Equations (25) and (30). 


\section{Appendix B: Description of Variables}

\begin{tabular}{|c|c|}
\hline Variables & Source \\
\hline $\begin{array}{l}\text { Real GDP per capita: International Dollar in } 2000 \text { Constant Prices, thousand } \\
\text { dollars. }\end{array}$ & Penn World Tables 6.2 \\
\hline Openness in constant prices: Percentage in 2000 constant prices. & Penn World Tables 6.2 \\
\hline Government share of real GDP: Percentage in 2000 Constant prices. & Penn World Tables 6.2 \\
\hline Investment share of real GDP: Percentage in 2000 Constant prices. & Penn World Tables 6.2 \\
\hline $\begin{array}{l}\text { Total reserves in months of imports: Amount of reserves in terms of the } \\
\text { number of months of imports of goods and services which can be paid. }\end{array}$ & $\begin{array}{l}\text { World Development Indi- } \\
\text { cators } 2006 \text { CD-ROM }\end{array}$ \\
\hline Inflation: Annual percentage change of the consumer price index. & $\begin{array}{l}\text { World Development Indi- } \\
\text { cators } 2006 \text { CD-ROM }\end{array}$ \\
\hline $\begin{array}{l}\text { Life expectancy at birth: Expresses the number of years a newborn can be } \\
\text { expected to live if prevailing patterns of mortality at the time of its birth are } \\
\text { same throughout its life. }\end{array}$ & $\begin{array}{l}\text { World Development Indi- } \\
\text { cators } 2006 \text { CD-ROM }\end{array}$ \\
\hline $\begin{array}{l}\text { Fertility rate: Number of children that are born to a woman if she lives to } \\
\text { the end of her childbearing years and bears children in accordance with current } \\
\text { age-specific fertility rates. }\end{array}$ & $\begin{array}{l}\text { World Development Indi- } \\
\text { cators } 2006 \text { CD-ROM }\end{array}$ \\
\hline $\begin{array}{l}\text { Economic proximity to major Europe: Bilateral trade with major Europe, } \\
\text { expressed as a ratio to GDP. }\end{array}$ & Barro and Lee (2005) \\
\hline $\begin{array}{l}\text { Political proximity to major Europe: Fraction of UN votes along with major } \\
\text { Europe. }\end{array}$ & Barro and Lee (2005) \\
\hline $\begin{array}{l}\text { Democracy index: Based of the Legal Index of Electoral Competitiveness } \\
\text { (LIEC); Codified with } 1 \text { if it has a value of } 6 \text { or larger which is the threshold for } \\
\text { democratic systems. }\end{array}$ & $\begin{array}{l}\text { World Bank Political Insti- } \\
\text { tutions Dataset }\end{array}$ \\
\hline Quota: Countries' quota in millions of standard drawing rights (SDR). & $\begin{array}{ll}\text { International Financial } \\
\text { Statistics }\end{array}$ \\
\hline $\begin{array}{l}\text { Loan-quota ratio: Sum of all current IMF loans a country is eligible to as a } \\
\text { share of its quota at the IMF. }\end{array}$ & $\begin{array}{l}\text { International Financial } \\
\text { Statistics and own calcu- } \\
\text { lation }\end{array}$ \\
\hline $\begin{array}{l}\text { Amount-drawn-to-amount-agreed ratio: The amount of all IMF loan pro- } \\
\text { gram funds a country actually draws expressed as a share of the original amount } \\
\text { agreed upon with the IMF. }\end{array}$ & $\begin{array}{l}\text { International Financial } \\
\text { Statistics and own calcu- } \\
\text { lations }\end{array}$ \\
\hline $\begin{array}{l}\text { Government Stability: Assesses the government's ability to carry out its de- } \\
\text { clared program(s), and its ability to stay in office. }\end{array}$ & $\begin{array}{ll}\text { International Country } \\
\text { Risk Guide }\end{array}$ \\
\hline $\begin{array}{l}\text { Internal Conflict: Assesses the political violence in the country and its actual } \\
\text { or potential impact on governance. }\end{array}$ & $\begin{array}{l}\text { International } \\
\text { Risk Guide }\end{array}$ \\
\hline Corruption: Assesses corruption within the political system. & $\begin{array}{l}\text { International } \\
\text { Risk Guide }\end{array}$ \\
\hline $\begin{array}{l}\text { Law and Order: Assesses the strength and impartiality of the legal system as } \\
\text { well as the popular observance of the law. }\end{array}$ & $\begin{array}{l}\text { International } \\
\text { Risk Guide }\end{array}$ \\
\hline $\begin{array}{l}\text { Ethnic Tensions: Assesses the degree of tension within a country attributable } \\
\text { to racial, nationality, or language divisions. }\end{array}$ & $\begin{array}{l}\text { International } \\
\text { Risk Guide }\end{array}$ \\
\hline $\begin{array}{l}\text { Bureaucracy Quality: Assesses the institutional strength and quality of the } \\
\text { bureaucracy. }\end{array}$ & $\begin{array}{l}\text { International } \\
\text { Risk Guide }\end{array}$ \\
\hline $\begin{array}{l}\text { Educational attainment: Total population aged } 15 \text { and over, average years of } \\
\text { school. }\end{array}$ & Worldbank \\
\hline $\begin{array}{l}\text { Institutional Index: Set up from the variables educational attainment, life ex- } \\
\text { pectancy, government stability, bureaucracy quality, corruption, law and order, } \\
\text { ethnic tensions and internal conflict }\end{array}$ & $\begin{array}{l}\text { International Country } \\
\text { Risk Guide and own } \\
\text { calculations }\end{array}$ \\
\hline Freedom Status: Assesses political rights and civil liberties in a country. & Freedom House \\
\hline Freedom of the Press: Assesses the degree of freedom of the press in a country. & Freedom House \\
\hline
\end{tabular}




\section{Appendix C: Countries Contained in Data Set ${ }^{28}$}

\begin{tabular}{|c|c|c|c|c|c|}
\hline Country & $\begin{array}{l}\text { Start : } \\
\text { end of } \\
\text { sample }\end{array}$ & $\begin{array}{l}\text { Years with Program Partici- } \\
\text { pation }\end{array}$ & Country & $\begin{array}{lr}\text { Start } & : \\
\text { end of } \\
\text { sample }\end{array}$ & $\begin{array}{l}\text { Years with Program Partici- } \\
\text { pation }\end{array}$ \\
\hline Algeria & $1977: 1991$ & $1989: 1991$ & Liberia & $1979: 1987$ & 1979:1985 \\
\hline Argentina & 1976:2004 & $1976: 1978 ; 1983: 2004$ & Madagascar & $1975: 2003$ & $1977: 1978 ; 1980: 1992 ; 1996: 2003$ \\
\hline Australia & 1975:2004 & $\%$ & Malawi & 1981:2002 & $1981: 1986 ; 1988: 2002$ \\
\hline Austria & $1975: 2004$ & $\%$ & Malaysia & $1975: 2003$ & $\%$ \\
\hline Bangladesh & $1987: 2003$ & $1987: 1993 ; 2003: 2003$ & Mali & $1989: 2003$ & $1989: 2003$ \\
\hline Belgium & $1975: 2001$ & $\%$ & Mexico & 1979:2004 & $\begin{array}{l}\text { 1979:1979; 1983:1993; 1995:1997; } \\
\text { 1999:2000 }\end{array}$ \\
\hline Bolivia & 1976:2003 & 1980:1980; 1986:2003 & Morocco & $1975: 2003$ & $1980: 1993$ \\
\hline Botswana & $1976: 2003$ & $\%$ & Mozambique & 1988:2003 & $1988: 2003$ \\
\hline Brazil & 1981:2003 & $\begin{array}{l}\text { 1983:1986; 1988:1990; 1992:1993; } \\
1998: 2003\end{array}$ & Namibia & 2003:2003 & $\%$ \\
\hline Burkina Faso & $1975: 2001$ & $1991: 2001$ & Netherlands & $1975: 2004$ & $\%$ \\
\hline Cameroon & $1977: 1995$ & 1988:1992; 1994:1995 & New Zealand & $1975: 2004$ & $\%$ \\
\hline Canada & $1975: 2004$ & $\%$ & Nicaragua & $1977: 2004$ & 1979:1979; 1991:2004 \\
\hline Chile & $1975: 2004$ & $1975: 1976 ; 1983: 1990$ & Niger & $1975: 2003$ & 1983:1991; 1994:2003 \\
\hline Colombia & $1975: 2003$ & $1999: 2003$ & Nigeria & 1977:2004 & $1987: 1987 ; 1989: 1992 ; 2000: 2001$ \\
\hline Congo, Rep. & 1986:2003 & $\begin{array}{l}1986: 1988 ; 1990: 1992 ; 1994: 1999 \\
\end{array}$ & Norway & $1975: 2004$ & $\%$ \\
\hline Costa Rica & $1977: 2004$ & $1977: 1977 ; 1980: 1983 ; 1985: 1997$ & Pakistan & $1976: 2004$ & $\begin{array}{l}\text { 1977:1978; 1980:1983; 1988:1991; } \\
\text { 1993:2004 }\end{array}$ \\
\hline Cote d'Ivoire & $1975: 2003$ & 1981:1992; 1994:2003 & Panama & $1977: 2003$ & $1977: 1987 ; 1992: 2002$ \\
\hline Cyprus & $1976: 2004$ & $1980: 1981$ & $\begin{array}{l}\text { Papua } \\
\text { Guinea }\end{array}$ & $1976: 2001$ & 1990:1992; 1995:1997; 2000:2001 \\
\hline Denmark & $1975: 2004$ & $\%$ & Paraguay & $1975: 2003$ & $2003: 2003$ \\
\hline $\begin{array}{l}\text { Dominican Re- } \\
\text { public }\end{array}$ & $1975: 2003$ & $1983: 1986 ; 1991: 1994 ; 2003: 2003$ & Peru & $1977: 2003$ & $1977: 1980 ; 1982: 1985 ; 1993: 2003$ \\
\hline Ecuador & $1976: 2004$ & $\begin{array}{l}\text { 1983:1992; 1994:1995; 2000:2001; } \\
\text { 2003:2004 }\end{array}$ & Philippines & $1977: 2004$ & $1977: 1981 ; 1983: 2000$ \\
\hline Egypt, Arab Rep. & $1977: 2003$ & $1977: 1981 ; 1987: 1988 ; 1991: 1998$ & Portugal & 1976:2004 & $1977: 1979 ; 1983: 1985$ \\
\hline El Salvador & 1976:2003 & $1980: 1983 ; 1990: 2000$ & Senegal & $1975: 2003$ & 1979:1992; 1994:2003 \\
\hline Finland & $1975: 2004$ & $1975: 1976$ & Sierra Leone & $1977: 2003$ & $\begin{array}{l}\text { 1977:1982; 1984:1989; 1994:1998; } \\
\text { 2001:2003 }\end{array}$ \\
\hline France & $1975: 2004$ & $\%$ & Singapore & $1975: 2004$ & $\%$ \\
\hline Gambia, The & 1978:1997 & 1978:1980; 1982:1991 & South Africa & $1975: 2004$ & $1976: 1977 ; 1982: 1983$ \\
\hline Germany & 1992:2004 & $\%$ & Spain & $1975: 2004$ & $1978: 1979$ \\
\hline Ghana & $1975: 2003$ & $1979: 1979 ; 1983: 1992 ; 1995: 2003$ & Sri Lanka & $1975: 2003$ & $\begin{array}{l}1975: 1975 ; 1977: 1981 ; 1983: 1984 ; \\
1988: 1995 ; 2001: 2003\end{array}$ \\
\hline Greece & $1976: 2004$ & $\%$ & Sudan & $1977: 2003$ & $1979: 1985$ \\
\hline Guatemala & $1977: 2003$ & $\begin{array}{l}\text { 1981:1984; 1988:1990; 1992:1994; } \\
2002: 2003\end{array}$ & Sweden & $1975: 2004$ & $\%$ \\
\hline Guinea-Bissau & $1988: 2003$ & 1988:1990; 1995:1998; 2000:2003 & Syrian Arab Rep. & $1977: 1988$ & $\%$ \\
\hline Haiti & $1975: 2000$ & $1975: 1990 ; 1995: 1999$ & Thailand & $1975: 2003$ & $\begin{array}{l}\text { 1978:1979; 1981:1983; 1985:1986; } \\
1997: 2000\end{array}$ \\
\hline Honduras & $1975: 2004$ & $\begin{array}{l}\text { 1979:1983; 1990:1997; 1999:2002; } \\
\text { 2004:2004 }\end{array}$ & Togo & $1975: 2003$ & $1979: 1998$ \\
\hline India & $1975: 2003$ & $1981: 1984 ; 1991: 1993$ & $\begin{array}{l}\text { Trinidad and To- } \\
\text { bago }\end{array}$ & $1975: 2003$ & 1989:1991 \\
\hline Indonesia & 1981:2004 & $1997: 2003$ & Tunisia & $1984: 2004$ & $1986: 1992$ \\
\hline Ireland & $1975: 2004$ & $\%$ & Turkey & $1975: 2004$ & $1978: 1985 ; 1994: 1996 ; 1999: 2004$ \\
\hline Israel & $1975: 2004$ & $1975: 1977$ & Uganda & 1981:2003 & $1981: 1984 ; 1987: 2003$ \\
\hline Italy & $1975: 2004$ & $1975: 1975 ; 1977: 1978$ & United Kingdom & $1975: 2004$ & $1975: 1978$ \\
\hline Jamaica & 1976:2003 & $1977: 1996$ & United States & $1975: 2004$ & $\%$ \\
\hline Japan & $1977: 2004$ & $\%$ & Uruguay & 1978:2004 & $1978: 1987 ; 1990: 1993 ; 1996: 2004$ \\
\hline Jordan & $1975: 2003$ & 1989:1990; 1992:2003 & Venezuela, RB & $1975: 2004$ & 1989:1993; 1996:1997 \\
\hline Kenya & $1975: 2003$ & $1975: 1986 ; 1988: 1994 ; 1996: 2003$ & Zambia & $1986: 2000$ & $1986: 1987,1995: 2000$ \\
\hline Korea, Rep. & 1976:2004 & $1976: 1977 ; 1980: 1987 ; 1997: 2000$ & Zimbabwe & 1980:1994 & $1981: 1984 ; 1992: 1994$ \\
\hline
\end{tabular}

\footnotetext{
${ }^{28}$ Major oil exporting countries, centrally planned and island economies have been excluded.
} 


\section{Appendix D: Results for the Random Effects Panel Model}

Table 12: Participation Selection Equation, RE Tobit Model

\begin{tabular}{|l|c|}
\hline Independent Variables & Coefficients \\
\hline Investment Share & $-1.174^{* * *}$ \\
\hline Inflation & $-0.016^{* *}$ \\
& {$[2.798]$} \\
\hline Government Share & {$\left[2.513^{* *}\right.$} \\
\hline Number of Years under IMF Programs & $0.021^{* * *}$ \\
\hline Staffshare at IMF & {$[7.562]$} \\
\hline Political Proximity to Major Europe & -0.029 \\
& {$[1.630]$} \\
\hline Reserves & $-0.123^{* *}$ \\
& {$[2.682]$} \\
\hline Current Account & -0.047 \\
& {$[0.692]$} \\
\hline Openness & -0.173 \\
& {$[0.903]$} \\
\hline Democracy & $-0.123^{* *}$ \\
\hline \hline Number of Observations for the selection equation: & {$[2.257]$} \\
\hline Note: Estimation results are obtained by estimating Equation (2). The dependent variable is the loan-quota
\end{tabular}

ratio. $t$-statistics are displayed in square brackets underneath the coefficient estimates. A “*” indicates

significance at the $10 \%$ level, a "**" indicates significance at the $5 \%$ level and a "***" indicates significance

at the $1 \%$ level. The regression uses annual data, the sample extends from 1975 to 2005 and the number of countries considered is 73. A description of all variables used is provided in Appendix B. 
Figure 6: Effect of IMF Loan Size Conditional on Actual Degree of Program Implementation, Annual Data, 1975 - 2005, 73 Countries.

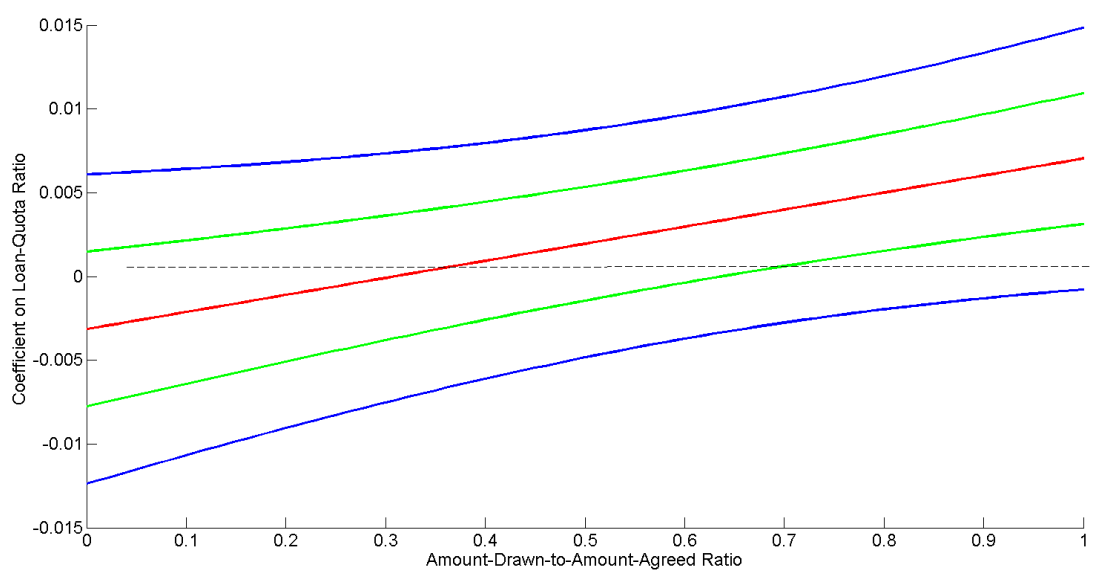

Figure 7: Coefficient of Loan-Quota Ratio Conditioned on a Country's Progress in Institutional Development, Annual Data, 1975 - 2005, 65 Countries.

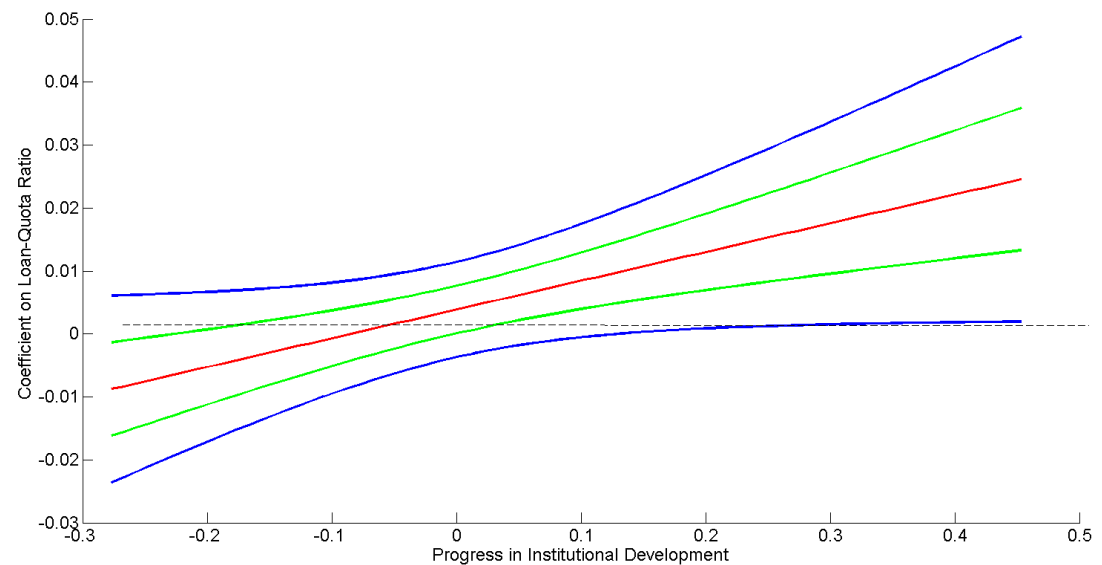


Figure 8: Intertemporal Effect of the Loan-Quota Ratio on a Country's Output Growth in the RE Model with Amount-Drawn-to-Amount-Agreed Ratio as Conditioning Variable.

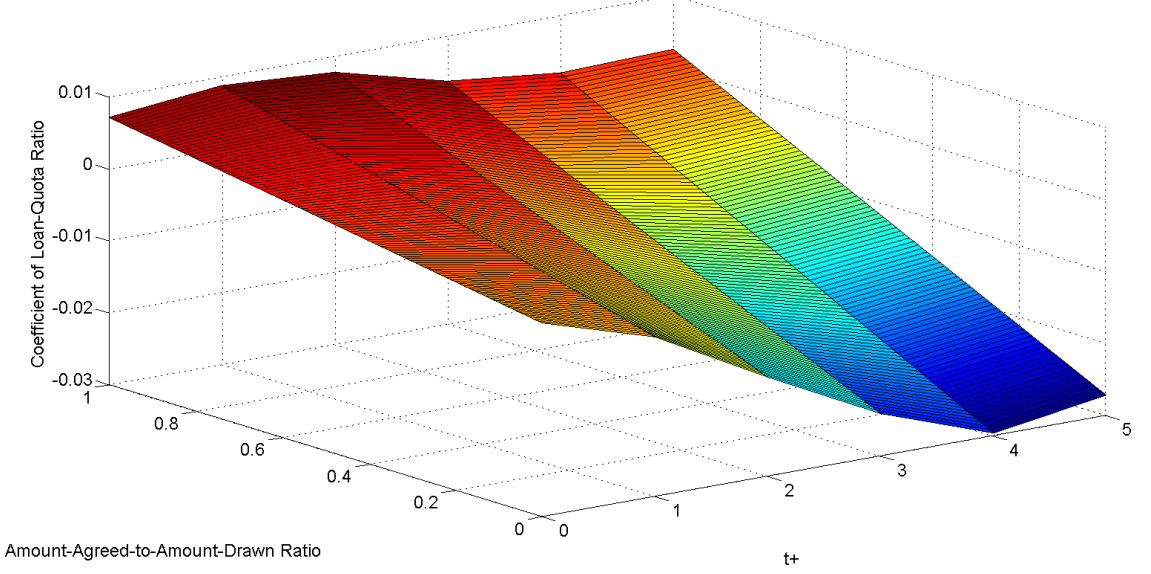

Figure 9: Intertemporal Effect of the Loan-Quota Ratio on a Country's Output Growth in the RE Model with the Progress in Institutional Development as Conditioning Variable.

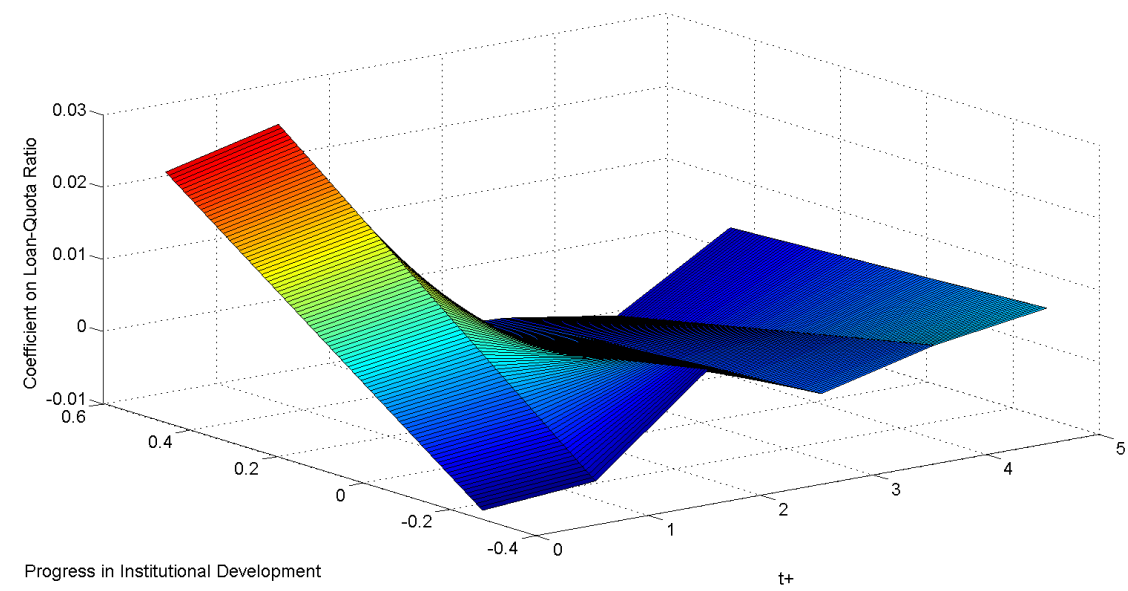


Table 13: Participation Effects Equation, RE Model

\begin{tabular}{|l|c|}
\hline Independent Variables & Coefficients \\
\hline Loan-Quota Ratio & -0.003 \\
& {$[0.682]$} \\
\hline Loan-Quota Ratio ${ }^{*}$ Drawn Ratio & $0.010^{*}$ \\
& {$[1.955]$} \\
\hline Investment Share & $0.138^{* *}$ \\
& {$[2.910]$} \\
\hline Inflation & $-0.003^{* * *}$ \\
& {$[4.873]$} \\
\hline Reserves & $0.022^{*}$ \\
& {$[1.882]$} \\
\hline \hline Number of Observations: & 931 \\
\hline Note: Estimation results are obtained by estimating Equation (1). The F-test of joint significance of the correc-
\end{tabular}

tion terms, $\tau_{1}$ and $\tau_{2}$, is not significant, but $\tau_{1}$ is individually significant at the $10 \%$ significance level, indicating correlation between the idiosyncratic error terms. The conditioning variable, amount-drawn-to-agreed-ratio, has been used as control variable also (not displayed), and is not significant. The dependent variable is real growth per capita GDP. $t$-statistics are displayed in square brackets underneath the coefficient estimates. A “*” indicates significance at the $10 \%$ level, a "**" indicates significance at the $5 \%$ level and a "***" indicates significance at the $1 \%$ level. The regression uses annual data, the sample extends from 1974 to 2005 and the number of countries considered is 73. A description of all variables used is provided in Appendix B.

Table 14: Growth Accounting, Annual Data, 1975 - 2005, 73 Countries

\begin{tabular}{|l|c|c|}
\hline Variables & Mean Effect & Contrib. in \% \\
\hline Loan-Quota Ratio & -0.003 & -14.29 \\
\hline Loan-Quota Ratio * Drawn Ratio & 0.005 & 21.91 \\
\hline Investment Share & 0.015 & 71.32 \\
\hline Inflation & -0.001 & -5.59 \\
\hline Democracy & 0.006 & 26.64 \\
\hline \hline Sum & 0.021 & 100.00 \\
\hline
\end{tabular}


Table 15: Participation Effects Equation, RE Model

\begin{tabular}{|l|c|}
\hline Independent Variables & Coefficients \\
\hline Loan-Quota Ratio & 0.004 \\
& {$[1.021]$} \\
\hline Loan-Quota Ratio ${ }^{*}$ Institutional Development & $0.046^{*}$ \\
& {$[1.955]$} \\
\hline Investment Share & $0.140^{*}$ \\
& {$[1.953]$} \\
\hline Inflation & $-0.003^{* * *}$ \\
& {$[4.011]$} \\
\hline Democracy & 0.002 \\
& {$[1.138]$} \\
\hline Reserves & 0.017 \\
& {$[1.404]$} \\
\hline \hline Number of Observations: & 852 \\
\hline Note: Estimation results are obtained by estimating Equation (1). The F-test of joint significance of the
\end{tabular}

correction terms, $\tau_{1}$ and $\tau_{2}$, is not significant. The conditioning variable, growth of the index of institutional quality, has been used as control variable also (not displayed), and is not significant. The dependent variable is real GDP per capita growth. $t$-statistics are displayed in square brackets underneath the coefficient estimates. A "** indicates significance at the $10 \%$ level, a "**" indicates significance at the $5 \%$ level and a "***" indicates significance at the $1 \%$ level. The regression uses annual data, the sample extends from 1975 to 2005 and the number of countries considered is 65. A description of all variables used is provided in Appendix B.

Table 16: Growth Accounting, Annual Data, 1975 - 2005, 65 Countries

\begin{tabular}{|l|c|c|}
\hline Variables & Mean Effect & Contrib. in \% \\
\hline Loan-Quota Ratio & 0.004 & 12.21 \\
\hline Loan-Quota Ratio * Instit. Dev. & 0.001 & 1.43 \\
\hline Investment Share & -0.001 & -4.04 \\
\hline Inflation & 0.009 & 28.55 \\
\hline Democracy & 0.004 & 13.68 \\
\hline \hline Sum & 0.021 & 100.00 \\
\hline
\end{tabular}


Table 17: Counterfactual Analysis, 1975 - 2005, Participating and NonParticipating Countries, Conditioning with the Amount Drawn to Amount Agreed Ratio, RE Specification

\begin{tabular}{|l|c|c|c|c|}
\hline Country years & Actual $^{a)}$ & Predicted $^{b)}$ & Predicted $^{c)}$ & Predicted $^{d)}$ \\
\hline Particip. & $0.61 \%$ & $0.61 \%$ & $0.44 \%$ & $2.91 \%$ \\
\hline Non-Particip. & $2.09 \%$ & - & $2.18 \%$ & $2.09 \%$ \\
\hline
\end{tabular}

a) Actual average growth.

b) Coefficient estimates used to compute the counterfactual are taken from the model specification involving only country years with participation in IMF loan programs.

c) Coefficient estimates used to compute the counterfactual are taken from the model specification involving only country years with participation in IMF loan programs. The independent variable loan-quota ratio is always set to zero.

d) Coefficient estimates used to compute the counterfactual are taken from the model specification involving only country years without participation in IMF loan programs.

Table 18: Counterfactual Analysis, 1975 - 2005, Participating and NonParticipating Countries, Conditioning with the Progress in Institutional Development, RE Specification

\begin{tabular}{|l|c|c|c|c|}
\hline Country years & Actual $^{a)}$ & Predicted $^{b)}$ & Predicted $^{c)}$ & Predicted $^{d)}$ \\
\hline Particip. & $0.57 \%$ & $0.57 \%$ & $0.13 \%$ & $2.61 \%$ \\
\hline Non-Particip. & $2.06 \%$ & - & $2.27 \%$ & $2.06 \%$ \\
\hline
\end{tabular}

a) Actual average growth.

b) Coefficient estimates used to compute the counterfactual are taken from the model specification involving only country years with participation in IMF loan programs.

c) Coefficient estimates used to compute the counterfactual are taken from the model specification involving only country years with participation in IMF loan programs. The independent variable loan-quota ratio is always set to zero.

d) Coefficient estimates used to compute the counterfactual are taken from the model specification involving only country years without participation in IMF loan programs. 
Table 19: Coefficients of the Loan-Quota Ratio in the RE Model in an Intertemporal Perspective with the Amount-Drawn-to-Amount-Agreed Ratio as Conditioning Variable

\begin{tabular}{|c|c|c|}
\hline Dep. Variable & Loan-Quota Ratio & Loan-Quota Ratio*Drawn Ratio \\
\hline$\frac{y_{t}-y_{t-1}}{y_{t}}$ & $\begin{array}{r}-0.003 \\
{[0.682]}\end{array}$ & $\begin{array}{l}0.010^{*} \\
{[1.955]}\end{array}$ \\
\hline$\frac{y_{t+1}-y_{t-1}}{y_{t+1}}$ & $\begin{array}{r}-0.008 \\
{[0.861]}\end{array}$ & $\begin{array}{l}0.017 \\
{[1.669]}\end{array}$ \\
\hline$\frac{y_{t+2}-y_{t-1}}{y_{t+2}}$ & $\begin{array}{r}-0.016 \\
{[1.226]}\end{array}$ & $\begin{array}{l}0.024^{* *} \\
{[2.060]}\end{array}$ \\
\hline$\frac{y_{t+3}-y_{t-1}}{y_{t+3}}$ & $\begin{array}{r}-0.024 \\
{[1.390]}\end{array}$ & $\begin{array}{l}0.028 * * \\
{[2.074]}\end{array}$ \\
\hline$\frac{y_{t+4}-y_{t-1}}{y_{t+4}}$ & $\begin{array}{r}-0.030 \\
{[1.265]} \\
\end{array}$ & $\begin{array}{l}0.032^{*} \\
{[1.751]}\end{array}$ \\
\hline$\frac{y_{t+5}-y_{t-1}}{y_{t+5}}$ & $\begin{array}{r}-0.027 \\
{[0.925]}\end{array}$ & $\begin{array}{l}0.030 \\
{[1.325]}\end{array}$ \\
\hline
\end{tabular}

indicates significance at the $5 \%$ level.

Table 20: Coefficients of the Loan-Quota Ratio in the RE Model in an Intertemporal Perspective with the Progress in Institutional Development as Conditioning Variable

\begin{tabular}{|c|c|c|}
\hline Dep. Variable & Loan-Quota Ratio & Loan-Quota Ratio*Drawn Ratio \\
\hline$\frac{y_{t}-y_{t-1}}{y_{t}}$ & $\begin{array}{l}0.004 \\
{[1.021]}\end{array}$ & $\begin{array}{l}0.046 \\
{[1.955]}\end{array}$ \\
\hline$\frac{y_{t+1}-y_{t-1}}{y_{t+1}}$ & $\begin{array}{l}0.006 \\
{[0.878]}\end{array}$ & $\begin{array}{l}0.049 \\
{[1.320]}\end{array}$ \\
\hline$\frac{y_{t+2}-y_{t-1}}{y_{t+2}}$ & $\begin{array}{l}0.002 \\
{[0.173]}\end{array}$ & $\begin{array}{r}-0.120 \\
{[0.274]}\end{array}$ \\
\hline$\frac{y_{t+3}-y_{t-1}}{y_{t+3}}$ & $\begin{array}{r}-0.020 \\
{[0.144]}\end{array}$ & $\begin{array}{r}-0.004 \\
0.050]\end{array}$ \\
\hline$\frac{y_{t+4}-y_{t-1}}{y_{t+4}}$ & $\begin{array}{r}-0.001 \\
{[0.036]}\end{array}$ & $\begin{array}{r}-0.013 \\
{[0.161]}\end{array}$ \\
\hline$\frac{y_{t+5}-y_{t-1}}{y_{t+5}}$ & $\begin{array}{l}0.004 \\
{[0.181]}\end{array}$ & $\begin{array}{r}-0.003 \\
{[0.038]}\end{array}$ \\
\hline
\end{tabular}

indicates significance at the $5 \%$ level. 


\section{References}

Barro, R.J. and J.W. Lee (2005): IMF Programs: Who is Chosen and What Are the Effects?, Journal of Monetary Economics, 52, 1245 - 1269.

Binder, M., C. Hsiao, and M.H. Pesaran (2005): Estimation and Inference in Short Panel Vector Autoregressions with Unit Roots and Cointegration, Econometric Theory, 21, $795-837$.

Binder, M. and C. Offermanns (2008): International Investment Positions and Exchange Rate Dynamics: A Dynamic Panel Analysis, Mimeo, Goethe University Frankfurt.

Bordo, M. and A.J. Schwartz (2000): Measuring Real Economic Effects of Bailouts: Historical Perspectives on How Countries in Financial Distress Have Fared With And Without Bailouts, Carnegie-Rochester Conference Series on Public Policy, 53, $81-167$.

Dicks-Mireaux, L., M. Mecagni, and S. Schadler (2000): Evaluating the Effect of IMF Lending to Low-Income Countries, Journal of Development Economics, 61, 495 - 526.

Dreher, A. (2006): IMF and Economic Growth: The Effects of Programs, Loans, and Compliance with Conditionality, World Development, 34, 769 -788 .

Evrensel, A.Y. (2002): Effectiveness of IMF-Supported Stabilization Programs in Developing Countries, Journal of International Money and Finance, $21,565-587$.

Fritz-Krockow, B. and P. Ramlogan (2007): International Monetary Fund Handbook, Washington D.C.: IMF Press.

Gourieroux, C., A. Monfort, E. Renault, and A. Trognon (1987): Generalised Residuals, Journal of Econometrics, 34, 5-32.

Heckman, J. (1979): Sample Selection Bias as a Specification Error, Econometrica, 47, $153-161$.

Heckman, J., H. Ichimura, and P. Todd (1998): Matching as an Econometric Evaluation Estimator, Review of Economic Studies, 65, 261 - 294. 
Hutchison, M. (2004): Selection Bias and Output Costs of IMF Programs, Mimeo, University of California - Santa Cruz.

Hutchison, M. and I. Noy (2003): Macroeconomic Effects of IMF-Sponsored Programs in Latin America: Output Costs, Program Recidivism and the Vicious Cycle of Failed Stabilizations, Journal of International Money and Finance, 22.

International Monetary Fund (2006): IMF-Supported Programs - Recent Staff Research, Issues Paper for an Evaluation by the Independent Evaluation Office of the IMF, xiii.

Killick, T. (1995): IMF Programmes in Developing Countries: Design and Impact, London: Routledge.

Mundlak, Y. (1978): On the Pooling of Time Series and Cross-Section Data, Econometrica, 46, $69-85$.

Nsouli, S.N., R. Atoyan, and A. Mourmouras (2006): Institutions, Program Implementation, and Macroeconomic Performance, in A. Mody and A. Rebucci (Eds.): IMF-Supported Programs - Recent Staff Research, Washington D.C.: IMF Press.

Polak, J.J. (1991): The Changing Nature of IMF Conditionality, OECD Development Centre Working Paper, 41.

Rodrik, D. (2009): One Economics Many Recipes, Princeton: Princeton University Press.

Semykina, A. and J.M. Wooldridge (2005): Estimating Panel Data Models in the Presence of Endogeneity and Selection: Theory and Application, Mimeo, Michigan State University.

Vella, F. (1998): Estimating Models with Sample Selection Bias: a Survey, Journal of Human Resources, 33, 127 - 169.

Vella, F. and M. Verbeek (1999): Two-Step Estimation of Panel Data Models with Censored Endogeneous Variables and Selection Bias, Journal of Econometrics, 90, 239 - 263.

Vreeland, J.R. (2003): The IMF and Economic Development, New York: Cambridge University Press. 


\section{CESifo Working Paper Series}

for full list see www.cesifo-group.org/wp

(address: Poschingerstr. 5, 81679 Munich, Germany, office@cesifo.de)

3097 Assar Lindbeck and Mats Persson, A Continuous Theory of Income Insurance, June 2010

3098 Thomas Moutos and Christos Tsitsikas, Whither Public Interest: The Case of Greece's Public Finance, June 2010

3099 Thomas Eichner and Thorsten Upmann, Labor Markets and Capital Tax Competition, June 2010

3100 Massimo Bordignon and Santino Piazza, Who do you Blame in Local Finance? An Analysis of Municipal Financing in Italy, June 2010

3101 Kyriakos C. Neanidis, Financial Dollarization and European Union Membership, June 2010

3102 Maela Giofré, Investor Protection and Foreign Stakeholders, June 2010

3103 Andrea F. Presbitero and Alberto Zazzaro, Competition and Relationship Lending: Friends or Foes?, June 2010

3104 Dan Anderberg and Yu Zhu, The Effect of Education on Martial Status and Partner Characteristics: Evidence from the UK, June 2010

3105 Hendrik Jürges, Eberhard Kruk and Steffen Reinhold, The Effect of Compulsory Schooling on Health - Evidence from Biomarkers, June 2010

3106 Alessandro Gambini and Alberto Zazzaro, Long-Lasting Bank Relationships and Growth of Firms, June 2010

3107 Jenny E. Ligthart and Gerard C. van der Meijden, Coordinated Tax-Tariff Reforms, Informality, and Welfare Distribution, June 2010

3108 Vilen Lipatov and Alfons Weichenrieder, Optimal Income Taxation with Tax Competition, June 2010

3109 Malte Mosel, Competition, Imitation, and R\&D Productivity in a Growth Model with Sector-Specific Patent Protection, June 2010

3110 Balázs Égert, Catching-up and Inflation in Europe: Balassa-Samuelson, Engel's Law and other Culprits, June 2010

3111 Johannes Metzler and Ludger Woessmann, The Impact of Teacher Subject Knowledge on Student Achievement: Evidence from Within-Teacher Within-Student Variation, June 2010 
3112 Leif Danziger, Uniform and Nonuniform Staggering of Wage Contracts, July 2010

3113 Wolfgang Buchholz and Wolfgang Peters, Equity as a Prerequisite for Stable Cooperation in a Public-Good Economy - The Core Revisited, July 2010

3114 Panu Poutvaara and Olli Ropponen, School Shootings and Student Performance, July 2010

3115 John Beirne, Guglielmo Maria Caporale and Nicola Spagnolo, Liquidity Risk, Credit Risk and the Overnight Interest Rate Spread: A Stochastic Volatility Modelling Approach, July 2010

3116 M. Hashem Pesaran, Predictability of Asset Returns and the Efficient Market Hypothesis, July 2010

3117 Dorothee Crayen, Christa Hainz and Christiane Ströh de Martínez, Remittances, Banking Status and the Usage of Insurance Schemes, July 2010

3118 Eric O'N. Fisher, Heckscher-Ohlin Theory when Countries have Different Technologies, July 2010

3119 Huw Dixon and Hervé Le Bihan, Generalized Taylor and Generalized Calvo Price and Wage-Setting: Micro Evidence with Macro Implications, July 2010

3120 Laszlo Goerke and Markus Pannenberg, 'Take it or Go to Court' - The Impact of Sec. 1a of the German Protection against Dismissal Act on Severance Payments -, July 2010

3121 Robert S. Chirinko and Daniel J. Wilson, Can Lower Tax Rates be Bought? Business Rent-Seeking and Tax Competition among U.S. States, July 2010

3122 Douglas Gollin and Christian Zimmermann, Global Climate Change and the Resurgence of Tropical Disease: An Economic Approach, July 2010

3123 Francesco Daveri and Maria Laura Parisi, Experience, Innovation and Productivity Empirical Evidence from Italy's Slowdown, July 2010

3124 Carlo V. Fiorio and Massimo Florio, A Fair Price for Energy? Ownership versus Market Opening in the EU15, July 2010

3125 Frederick van der Ploeg, Natural Resources: Curse or Blessing?, July 2010

3126 Kaisa Kotakorpi and Panu Poutvaara, Pay for Politicians and Candidate Selection: An Empirical Analysis, July 2010

3127 Jun-ichi Itaya, Makoto Okamura and Chikara Yamaguchi, Partial Tax Coordination in a Repeated Game Setting, July 2010

3128 Volker Meier and Helmut Rainer, On the Optimality of Joint Taxation for NonCooperative Couples, July 2010 
3129 Ryan Oprea, Keith Henwood and Daniel Friedman, Separating the Hawks from the Doves: Evidence from Continuous Time Laboratory Games, July 2010

3130 Mari Rege and Ingeborg F. Solli, The Impact of Paternity Leave on Long-term Father Involvement, July 2010

3131 Olaf Posch, Risk Premia in General Equilibrium, July 2010

3132 John Komlos and Marek Brabec, The Trend of BMI Values by Centiles of US Adults, Birth Cohorts 1882-1986, July 2010

3133 Emin Karagözoğlu and Arno Riedl, Information, Uncertainty, and Subjective Entitlements in Bargaining, July 2010

3134 John Boyd, Gianni De Nicolò and Elena Loukoianova, Banking Crises and Crisis Dating: Theory and Evidence, July 2010

3135 Michael R. Baye, Dan Kovenock and Casper G. de Vries, The Herodotus Paradox, July 2010

3136 Martin Kolmar and Hendrik Rommeswinkel, Group Contests with Complementarities in Efforts, July 2010

3137 Carolina Manzano and Xavier Vives, Public and Private Learning from Prices, Strategic Substitutability and Complementarity, and Equilibrium Multiplicity, July 2010

3138 Axel Löffler, Gunther Schnabl and Franziska Schobert, Inflation Targeting by Debtor Central Banks in Emerging Market Economies, July 2010

$3139 \mathrm{Yu}-\mathrm{Fu}$ Chen and Michael Funke, Global Warming and Extreme Events: Rethinking the Timing and Intensity of Environmental Policy, July 2010

3140 Lawrence M. Kahn, Labor Market Policy: A Comparative View on the Costs and Benefits of Labor Market Flexibility, July 2010

3141 Ben J. Heijdra, Jochen O. Mierau and Laurie S.M. Reijnders, The Tragedy of Annuitization, July 2010

3142 Erkki Koskela, Outsourcing Cost and Tax Progression under Nash Wage Bargaining with Flexible Outsourcing, July 2010

3143 Daniel Osberghaus and Christiane Reif, Total Costs and Budgetary Effects of Adaptation to Climate Change: An Assessment for the European Union, August 2010

3144 Philip E. Graves, Benefit-Cost Analysis of Environmental Projects: A Plethora of Systematic Biases, August 2010

3145 Sabrina Di Addario and Daniela Vuri, Entrepreneurship and Market Size. The Case of Young College Graduates in Italy, August 2010 
3146 Shoshana Amyra Grossbard and Alfredo Marvăo Pereira, Will Women Save more than Men? A Theoretical Model of Savings and Marriage, August 2010

3147 Jarko Fidrmuc, Time-Varying Exchange Rate Basket in China from 2005 to 2009, August 2010

3148 Ilja Neustadt and Peter Zweifel, Is the Welfare State Sustainable? Experimental Evidence on Citizens' Preferences for Redistribution, August 2010

3149 Marcus Dittrich and Andreas Knabe, Wage and Employment Effects of Non-Binding Minimum Wages, August 2010

3150 Shutao Cao, Enchuan Shao and Pedro Silos, Fixed-Term and Permanent Employment Contracts: Theory and Evidence, August 2010

3151 Ludger Woessmann, Cross-Country Evidence on Teacher Performance Pay, August 2010

3152 Lorenzo C. G. Pozzi, Casper G. de Vries and Jorn Zenhorst, World Equity Premium Based Risk Aversion Estimates, August 2010

3153 Volker Grossmann, Thomas M. Steger and Timo Trimborn, Dynamically Optimal R\&D Subsidization, August 2010

3154 Alexander Haupt, Tim Krieger and Thomas Lange, A Note on Brain Gain and Brain Drain: Permanent Migration and Education Policy, August 2010

3155 António Afonso and Christophe Rault, Long-run Determinants of Sovereign Yields, August 2010

3156 Franziska Tausch, Jan Potters and Arno Riedl, Preferences for Redistribution and Pensions. What can we Learn from Experiments?, August 2010

3157 Martin Kolmar and Andreas Wagener, Inefficient Group Organization as Optimal Adaption to Dominant Environments, August 2010

3158 Kai Carstensen, Klaus Wohlrabe and Christina Ziegler, Predictive Ability of Business Cycle Indicators under Test: A Case Study for the Euro Area Industrial Production, August 2010

3159 Horst Rottmann and Timo Wollmershäuser, A Micro Data Approach to the Identification of Credit Crunches, August 2010

3160 Philip E. Graves, Appropriate Fiscal Policy over the Business Cycle: Proper Stimulus Policies Can Work, August 2010

3161 Michael Binder and Marcel Bluhm, On the Conditional Effects of IMF Program Participation on Output Growth, August 2010 